\title{
When REAL PEOPLE BECOME FiCTIONAL: THE COLLISION OF TRADEMARK, COPYRIGHT, AND PUBLICITY RIGHTS IN ONLINE STORIES ABOUT CELEBRITIES
}

\author{
Stacey M. Lantagne*
}

\begin{abstract}
Fanficion is frequently defined as the writing of fiction involving the characters or setting of someone else's creation. However, there is a subset of fanfiction that is known as Real Person Fiction, or RPF. This subset writes stories not about other people's fictional creations but about real people, whether they be hockey players or movie stars, and it has long been the scene of heated debate in the fan community. Some fans who readily and enthusiastically engage with fanfiction draw strict "squick" lines about RPF and call it "creepy" and "disturbing."

Perhaps for this reason, scholars have paid little attention to online stories about celebrities in evaluations of fan activities. From a legal standpoint, however, these stories are much more easily defensible than fanfiction. As they involve real people instead of fictional creations, they do not implicate copyright and so are protected from the charges of copyright infringement that could be levied at other pieces of fanfiction. Their First Amendment implications and non-commercial speech aspects tend to protect them from attacks using trademark law. Finally, their embrace of wildly unlikely fictional scenarios - ranging from movie stars recast as baristas to pregnant male hockey players - shields them from any possible liability for privacy right or publicity right violations.

This Article concludes that online stories about celebrities are currently legally protected, possibly more so than more traditional forms of fanfiction and even some more mainstream forms of storytelling. It further concludes that these stories should be so protected as a matter of sound policy.
\end{abstract}

* Assistant Professor of Law, The University of Mississippi School of Law. Prof. Lantagne wishes to thank participants of the Midwest Popular Culture Association and Midwest American Culture Association Annual Conference, the University of Arkansas School of Law Speaker Exchange, the University of Mississippi School of Law Faculty Writing Groups, and the University of Mississippi School of Law Faculty Colloquium for valuable comments. She also wishes to thank the University of Mississippi School of Law for the generous Dean's Research Grant that supported the research and writing of this Article. 


\section{INTRODUCTION}

"The Social Network" is a movie from 2010 allegedly about the creation of Facebook. It tells the story of real-life person Mark Zuckerberg, his friend Eduardo Saverin, and other assorted real-life characters that were part of the Facebook "story." "The Social Network" was highly regarded and nominated for several Oscars, including Best Picture. ${ }^{1}$

It lost the Best Picture Oscar to "The King's Speech," a movie allegedly about King George VI's overcoming of his stutter to deliver an impassioned speech helping to inspire Great Britain in its defiance against Hitler. ${ }^{2}$ Movies like these-about "real people"-are common and currently dominate awards shows. The 2014 Oscars alone contained movies like "Selma," "The Imitation Game," and "The Theory of Everything," all of them dramatizing stories about real people. ${ }^{3}$ The 2015 Oscars likewise involves movies like "Bridge of Spies," "Spotlight," "Steve Jobs," and "The Danish Girl." The hit, Grammy-winning musical "Hamilton" on Broadway likewise tells the story of real-life person Alexander Hamilton and the rest of the Founding Fathers. ${ }^{5}$

These are not the only stories about real people that are being told, however. "The Social Network" might be about Eduardo Saverin and Mark Zuckerberg. But there is also a piece of fiction available online called "the time is come when the day is done," by moogle62, in which Eduardo Saverin and Mark Zuckerberg fight off the zombie apocalypse together. There is an online story called "Stay Awake When I'm Asleep," by harriet_vane, in which Jesse Eisenberg and Andrew Garfield, the actors who starred in "The Social Network," fall in love on the set and raise a baby together. ${ }^{7}$ Another online story called "Ten Cups of Coffee (A Love Story)," also by harriet_vane, has Andrew Garfield as a barista who falls for Jesse Eisenberg's harried coffee-shop-regular grad student. ${ }^{8}$ And there is a story available online called "After," in which Harry Styles and the rest of his One Direction bandmates are college students. This story has been

1. See The Social Network, IMDB, http://www.imdb.com/title/tt1285016/?ref_=fn_al_tt_1 (last visited Feb. 22, 2016).

2. Id.

3. See The 86th Academy Awards, 2014, (March 2, 2014), https://www.oscars.org/oscars/ceremonies/2014.

4. See Oscar Nominations 2015: Full List, VARIETY, (Jan. 15, 2015), (http://variety.com/2015/film/news/oscar-nominations-2015-full-list-academyaward-nominees-1201405517/.

5. See Devon Ivie, Watch the Hamilton Performance at the Grammy's Because This Will Be the Closest Most Of Us Will Ever Get to Actually Seeing Hamilton, VultuRe, (Feb. 15, 2016), http://www.vulture.com/2016/02/watch-the-hamiltonperformance-at-the-grammys.html.

6. See moogle62, the time has come when the day is done, LiveJournal, (May 9, 2011), http://mark-eduardo.livejournal.com/376407.html.

7. See harriet_vane, Stay Awake When I'm Asleep, Archive OF Our Own, (Jan. 16, 2012), http://archiveofourown.org/works/321694.

8. See harriet_vane, Ten Cups of Coffee (A Love Story), ArChIVE OF Our Own, (Jan. 16, 2012), http://archiveofourown.org/works/321697 (last visited Feb. 22, 2016). 
Journal of Law, Technology \& the Internet · Vol. $7 \cdot 2016$

When Real People Become Fictional

viewed by more than a billion people. ${ }^{9}$ To put this in perspective, the average published book sells just 3,000 copies over the course of its lifetime. ${ }^{10}$ A publishing company paid six figures for the privilege of publishing "After."11 They changed the names of the One Direction band members $^{12}$ and started selling the novel. A film adaptation is in the works. ${ }^{13}$

It's clear that telling stories about real people is a burgeoning method of creativity. But most people seem to instinctively treat the Oscarnominated movies differently from the online stories just described. This Article seeks to determine whether there is a legally justifiable reason to treat such online stories differently. It analyzes how they differ from Oscarnominated films, and if that difference is a reason to treat them differently under the law, or if, instead, online fiction about celebrities-what fan circles would call "RPF" or Real Person Fic ${ }^{14}$ — are legally protected.

Despite the genre's increased prominence, potential for financial reward, and controversial status within the fan community, very little has been written about the fan phenomenon of "RPF," which differs from traditional fanfiction in one vital respect: It doesn't implicate copyright. This Article tackles the novel issue of the legality of online fiction about celebrities. It concludes that, although the frequent battles over this form of storytelling in fandom communities might lead one to assume otherwise, such online stories legally protected. In fact, what fans would call "RPF" is probably more legally acceptable under current precedent than more traditional forms of fanfiction and also more traditional forms of mainstream storytelling about celebrities. This Article further concludes that this current legal regime is a desirable outcome from a policy standpoint.

\section{Defining Online Stories About Celebrities}

Most fans, when asked about RPF, know exactly what it refers to and have strong opinions about it. These furious debates involve knee-jerk

9. See Dan Kois, How One Direction Superfan Anna Todd Went From Waffle House Waitress to Next-Big-Author With Erotic Fan-Fic Series 'After', Billboard (July 17, 2015, 5:19 PM), http://www.billboard.com/articles/magazine/6634431/anna-toddafter-one-direction-fan-fiction-book-deal-movie-rights-profile.

10. See Kameron Hurley, The Cold Publishing Equations: Books Sold + Marketability + Love, (Sept. 17, 2015), http://www.kameronhurley.com/the-cold-publishingequations-books-sold-marketability-love/.

11. See Elizabeth Minkel, The truth behind that six-figure deal for Harry Styles fan fiction, NewStaTESMAN (June 24, 2014).

12. See Kois, supra note 9; Minkel, supra note 11.

13. See Mike Fleming Jr., 'After' Movie: Paramount Acquires Rights to Wattpad Book by Anna Todd, DeAdline, (Oct. 16, 2014), http://deadline.com/2014/10/aftermovie-rights-wattpad-book-anna-todd-paramount-852926/.

14. See Trinity, Trinity, RPS on the Net, CityBEAT, https://web.archive.org/web/20010801230323/http://citybeat.slashcity.org/article.p hp?sid=29 (last visited Sept. 18, 2015) (defining fanfiction RPF as stories "written not about characters, but about actors, musicians, and other celebrities"). 
reactions and obscure the complication that online fiction about celebrities is actually fairly tricky to differentiate from more common forms of mainstream story-telling that are unremarkable and uncontroversial. It is dangerous to set a precedent that these stories are different merely because they are found "online" and not created by those authors accepted and lauded by awards ceremonies. Nor is it accurate to consider these online stories as unique because of their lack of commercialism, considering that they have now begun to be commercialized. Actually, the best way to differentiate online fiction about celebrities from the more mainstream movies, books, and plays about real people are the online stories' aggressive fictionality.

\section{A. The Online Controversy over Online Stories About Celebrities}

Fan battles over the existence of online fiction about celebrities flare up with occasional regularity, ${ }^{15}$ inspiring strong emotions on both sides of the question. ${ }^{16}$ Some fans who readily and enthusiastically engage with fanfiction draw strict "squick" "icky." 19 One fan critic dismissed the genre in one fell swoop by saying

15. See hederahelix, RPS: Another Persepctive [sic], FANTHROPOLOGY - THE StUdy of FANDOM (Mar. 22, 2005, 11:47 AM), http://fanthropology.livejournal.com/33447.html ("I really, really don't want to get into the 'RPS is evil' debate *again,* as I've seen it rehashed more often than I care to think about."); leucocrystal, Comment to RPF - just stop doing it, KHYBER (Feb. 19, 2009), http://that-khyber.livejournal.com/2009/02/18/.

16. See Kristina, Real Person Fiction, The FAnfiC Symposium (Oct. 30, 2005), http://www.trickster.org/symposium/symp178.htm; Aja Romano, 19th-century fans were totally into a Napoleon/Alexander romance, THE DAILY DoT (Oct. 18, 2013); Minkel, supra note 11.

17. See nospeud, Fact, Fiction, and the Writer's Responsibility to the Truth, THE FANFIC SYMPOSIUM (Sept. 16, 2003), http://www.trickster.org/symposium/symp137.html; joudama, Because We Love Our Gods: Mythoi, Logoi, and Real Person Slash, The FAnFiC Symposium (Feb. 4, 2003), http://www.trickster.org/symposium/symp114.html; mab_browne, Comment to RPF?!, FAnTHROPOlOGY - The StUdy OF FAndom (Aug. $\overline{1} 1,2005$, 11:50 PM), http://fanthropology.livejournal.com/117158.html; leucocrystal, Comment to RPF - just stop doing it, KHYBER (Feb. 19, 2009), http://thatkhyber.livejournal.com/2009/02/18/; ex_devil323, Comment to [ all i do is talk], LiveJournal (Dec. 6, 2006).

18. Anonymous, Comment to RPS: Another Persepctive [sic], FANTHROPOLOGY - ThE STUDY OF FANDOM (Mar. 24, 2005, 4:12 AM), http://fanthropology.livejournal.com/33447.html; see also that_khyber, RPF - just stop doing it, KHYBER (Feb. 18, 2009), http://thatkhyber.livejournal.com/2009/02/18/.

19. Zubird, Comment to RPF?!, Fanthropology - The Study of Fandom (Aug. 11, 2005, 10:33 PM), http://fanthropology.livejournal.com/117158.html; see also Michelle Christian, RPS, Boybands, and Dead Guy RPS, The FAnfIC Symposium (June 21, 2003), http://www.trickster.org/symposium/symp124.html; Kristina, supra note 16. Indeed, for some people this is the appeal of fanfiction RPF. See Trinity, supra note 14 ("The draw for me ... is that... [it] offered that little 
that "there can be no underlying literary justification of it as good stories that people want to tell about archetypical, interesting characters in unique universes and situations." 20

The historical aggression against fan stories about celebrities led to a long period of such stories existing on the underside of the Internet, ${ }^{21}$ frequently hidden from view as much as could possibly be accomplished. This involved exclusion from the main archiving sites, ${ }^{22}$ passwordprotecting the websites where such stories were contained, ${ }^{23}$ and removing these websites from search engines' indexing tools so that they could not be accidentally located. ${ }^{24}$ Considering how easy it is to find so many things on the Internet, these protective security measures historically taken by the fans engaged in these celebrity-centric stories indicate how uncertain these fans felt about the practice. While many fans defended their stories, ${ }^{25}$ even the fans that write or read the online stories expressed dismay with themselves and felt guilty for their activities.

Fans' seemingly internalized sense of guilt over online fiction about celebrities and the "instinctive" arguments ${ }^{26}$ offered against it cloak the actual complexity of the question of the stories' propriety. In fact, the very vague language used to argue against these online stories both acknowledges and dismisses its complexity in one fell swoop: "[I]t feels different. I don't know how or why, but it does," 27 argues one person, while another admits, "I'm not sure why I feel this way - I only know that I do". ${ }^{28}$ Many fans' steadfast proclamations that online fiction about

frisson of naughtiness .... [Fanfiction RPF] is forbidden by almost everyone, everywhere, so it will always be naughty and kinky.").

20. Trinity, supra note 14.

21. See Trinity, supra note 14 (referring to fanfiction RPF as pervasive but "stuffed in the bottom of drawers or tucked away in a disguised folder in the computer, taken out and passed around to trusted friends who are told 'you didn't see this, this doesn't exist, pretend this never happened"').

22. See Kristina, supra note 16; History of Real Person Fic, FAN History Wiki, http://fanhistory.com/wiki/History_of_Real_Person_Fic (last modified Dec. 5, 2008).

23. See nopseud, supra note 17; unlovablehands, Comment to RPS and privacy, LiVEJOURNAL (Apr. 29, 2007, $2: 17 \quad$ PM), http://ignazwisdom.livejournal.com/2007/04/29/.

24. See nopseud, supra note 17; ignazwisdom, Comment to RPS and privacy, $\begin{array}{lllll}\text { LIVEJOURNAL (Apr. } & 29, & 2007, & 7: 30 & \text { PM), }\end{array}$ http://ignazwisdom.livejournal.com/2007/04/29/.

25. The statement about lack of justification is, of course, denied by fanfiction RPF supporters. See Trinity, supra note 14; Anonymous, Comment to RPS on the Net, CityBeat, https://web.archive.org/web/20010801230323/http://citybeat.slashcity.org/article.p hp? sid=29 (last visited Sept. 18, 2015).

26. Nospeud, supra note 17; see also that_khyber, supra note 18 (calling it a "gut feeling").

27. Christian, supra note 19.

28. Justine, I Don't Believe in Real People, The Fanfic Symposium (Mar. 4, 2003), http://www.trickster.org/symposium/symp116.html; see also cealchylle, Comment to Compartmentalization and RPF, THAT WHICH AMUSES THE CAT (Dec. 11, 2007, 
celebrities is "wrong" might lead people to conflate this question with its legality, ${ }^{29}$ while obscuring the fact that, in actuality, it strongly resembles storytelling that is used by much of the population without comment on a daily basis. ${ }^{30}$ Unless these stories about online celebrities are somehow different from mainstream stories about real people like celebrities, then there is no reason to be at all alarmed about the stories.

After all, there is much legal precedent that movies like "The Social Network," "Selma," and "The Imitation Game" are not just legally permissible, but First-Amendment-protected, such that they can't usually be blocked by the real people who are characters in them. ${ }^{31}$ A recent judicial dissent sums up nicely the importance of mainstream "RPF" to our contemporary entertainment: "Absent the use of actual footage, the motion picture Forrest Gump might as well be just a box of chocolates. Without its historical characters, Midnight in Paris would be reduced to a pedestrian domestic squabble." 32 Unless online fiction about celebrities is different in some appreciable way from the movies just mentioned, one would assume they enjoy the same creative First Amendment protection, their often controversial nature online notwithstanding.

\section{B. The Dangerous Focus on the Identity of the Author}

One obvious way in which online fiction about celebrities differs from the Oscar-nominated movies is that the online fiction about celebrities is created by people on the Internet. It is not, however, correct to say that these stories are different because they are created by fans. The truth is,

5:51 AM), http://fairestcat.livejournal.com/449918.html ("I don't know, but to me it crosses a line that I'm not comfortable with.").

29. See hederahelix, supra note 15 (noting that "a lot of the negative reaction to RPS" seems to come from the idea that it "exposes fandom to possible legal action"); Dara Sloan, RPS Reality Check, ThE FANFIC SYMPOSIUM (Sept. 4, 2001); partly_bouncy, Comment to RPF?!, FANTHROPOLOGY - THE STUDY OF FANDOM (Aug. 11, 2005, 10:19 PM), http://fanthropology.livejournal.com/117158.html; zubird, Comment to RPF?!, FAnTHRopology - The Study of FAndom (Aug. 11, 2005, 10:28 PM), http://fanthropology.livejournal.com/117158.html; see also winterlive, [ all $i$ do is talk ], LiveJournAL (Dec. 5, 2006), $\mathrm{http}: / /$ winterlive.livejournal.com/311855.html.

30. See turlough, Comment to RPS and privacy, LiveJournal (Apr. 29, 2007, 4:10 PM), http://ignazwisdom.livejournal.com/2007/04/29/; History of Real Person Fic; winterlive, Comment to [ an inspired word will come across your tongue], LiVEJoURNAL (Sept. 14, 2007, 1:32 AM), http://winterlive.livejournal.com/389407.html; Emily_shore, Don't think twice, it's all right: ten easy excuses for RPF writers, THE ARTIST FORMERLY KNOWN AS NARAHT (Jan. 14, 2009, 5; $11 \quad$ PM), http://emilyshore.livejournal.com/286793.html; moosesal, Comment to [ all I do is talk], LiVEJOURNAL (Dec. 6, 2006, 3:29:25 AM), $\mathrm{http}: / /$ winterlive.livejournal.com/311855.html.

31. See, e.g., Ninth Circuit Tosses Hurt Locker Case, Rothman's RoAdmap to the Right OF Publicity (Feb. 17, 2016).

32. In re NCAA Student-Athlete Name \& Likeness Licensing Litigation, 724 F.3d 1268, 1290 (9th Cir. 2013) (Thomas, J., dissenting). 
Journal of Law, Technology \& the Internet · Vol. $7 \cdot 2016$

When Real People Become Fictional

most mainstream "RPF" is also created by "fans," or at least people who are interested in the people they're writing about. The difference between online fiction about celebrities and Oscar-nominated movies isn't the fan status of the author; rather, it's the power and access status of the author.

To dismiss all online fiction about celebrities based on a definition of who the authors are is to make a definitive statement that U.S. law should treat methods of creativity differently based on whether it has been written by people who are or aren't famous or are or aren't part of the "in" crowd being paid to write about such things, It would set an alarming precedent outlawing an entire form of creativity because it isn't written by the "right" people. ${ }^{33}$ Regulating speech based on the identity of the speaker is surely a slippery constitutional slope. ${ }^{34}$ If fanfiction RPF is considered different from mainstream RPF, it must be for some reason other than the abstract and relative popularity of the creator.

\section{The Commercial Nature of Online Stories About Celebrities}

It used to be that the main difference between the mainstream stories about real people and their online counterparts was that the online stories weren't commercialized. Specifically, they weren't making any money. ${ }^{35}$

While you can run afoul of copyright law even without making any money, practically speaking it is easier to stay under the radar if your activity has no commercial impact. Now, however, online fiction about celebrities has started making money. The writer of "After" earned $\$ 500,000$ for her stories and is a full-time writer now as a result. ${ }^{36}$ Wattpad, the website that hosted "After" and gave it the billion views that led to its prominence among publishing companies, is unabashedly in the business of making money and is seeking to build a profit model around its contentwhich is, to a large extent, stories about the band One Direction in the vein

33. See Martin H. Redish \& Kelsey B. Shust, The Right of Publicity and the First Amendment in the Modern Age of Commercial Speech, 56 Wm. \& Mary L. Rev. 1443, 1475 (Mar. 2015) (noting the danger of only protecting "speech that has been creatively altered to the court's liking"). Such a divide can already be seen, with critics not even blinking over more aggressively fictional forms of celebrity stories when they are professionally produced. See, e.g., Ben Siegel, Funny guy: Kurt Erb delivers in a refreshing one-man show, 9/24/15 BUFF. NEws 12 (Sept. 24, 2015); Jake Wilson, Fifties film icon emerges from nervous beginnings, 9/10/15 Sydney Morning Herald (Austl.) 29 (Sept. 10, 2015); Tim Parks, Imagined Meetings with Joyce, Dickens, Hardy, and Lawrence, THE New YORKER (Sept. 15, 2015).

34. See Redish \& Shust, supra note 33, at 1488. The law is full of biases in favor of particular speakers, although open acknowledgement of these is not often acknowledged. See Rebecca Tushnet, A Mask That Eats into the Face: Images and the Right of Publicity, 38 COLUM. J.L. \& ARTS 157, 169-70 (Winter 2015).

35. See counterfeitcoin, Comment to RPS and privacy, LiveJournal (Apr. 29, 2007, 6:25 PM), http://ignazwisdom.livejournal.com/2007/04/29/.

36. See Minkel, supra note 11. 
Journal of Law, Technology \& the Internet · Vol. $7 \cdot 2016$

When Real People Become Fictional

of "After." ${ }^{37}$ Other publishing companies have certainly taken notice of the attention One Direction fanfiction RPF has received, beginning to openly mine Wattpad for their latest books. ${ }^{38}$ In addition, Amazon's selfpublishing platform has permitted some fanfiction RPF authors to seek to sell their stories. ${ }^{39}$

Years ago, one writer of online stories about celebrities mused, "I wonder whether it's becoming more acceptable in a mainstream sense, or whether it will stay forever peripheral?" $"$ The answer is clearly that these online stories about celebrities are ready for their close-up. Buoyed by the success of Wattpad, fanfiction RPF will doubtless continue to creep more fully into the spotlight, complete with financial compensation. ${ }^{41}$ Therefore, online fiction about celebrities can no longer be considered "noncommercial" in any real manner, to the extent it ever really could. And, as online stories about celebrities begin to generate more dollars, their legal status will surely be more intensely questioned. ${ }^{42}$

\section{The Aggressive Fictionality of Online Stories About Celebrities}

The main difference between online fiction about celebrities and the more mainstream fiction about celebrities is the aggressive fictionality of the online version. In "The Social Network," Mark and Eduardo meet as students at Harvard - just as happened in real life - and go on to create Facebook. ${ }^{43}$ In the Eisenberg and Garfield RPF example used, nothing in

37. See Mike Fleming Jr., 'After' Movie: Paramount Acquires Rights to Wattpad Book by Anna Todd, DeAdline (Oct. 16, 2014, 8:00 AM), http://deadline.com/2014/10/after-movie-rights-wattpad-book-anna-toddparamount-852926/ ("Wattpad is a top entertainment destination with thousands of new stories shared every day. We expect to see many more blockbusters and bestsellers emerge from the platform."); Amanda Michelle Steiner, Fifty Shades of Grey and 9 More Examples of When Fan Fiction Became Blockbusters, People (Feb. 12, 2015, 2:30 PM), http://www.people.com/article/fifty-shades-of-grey-fanfiction-mainstream-examples-fanworks ("Wattpad ... is absolutely rife with One Direction fic."); Minkel, supra note 11.

38. See What If I'm Contacted by a Publisher?, (Feb. 9, 2016), https://support.wattpad.com/hc/en-us/articles/202746340-What-If-I-m-Contactedby-a-Publisher-.

39. See Drew Mackie, Couple Sues Amazon, Apple over Erotic Rob Gronkowski EBook A Gronking to Remember, PeOPle (Apr. 29, 2015, 12:50 AM), http://www.people.com/article/gronking-to-remember-lawsuit-rob-gronkowskierotic-book; Karen Hines, Fan fiction centred around Prime Minister Justin Trudeau takes a disturbing and impassioned turn, CALGary Herald (Nov. 27, 2015).

40. Emily_shore, Comment to Don't think twice, it's all right: ten easy excuses for RPF writers, THE ARTIST Formerly KNOWn AS NARAHT (Jan. 18, 2009, 3:07 PM), http://emily-shore.livejournal.com/286793.html.

41. Trinity, supra note 14 ("[M] ore and more it seems that [fanfiction RPF] is coming out from the bottom of the drawers, off the hard drive, and appearing on the net.").

42. See Nathan Luke, Social media defamation actions soar, 9/9/15 MONDAQ (Sept. 9, 2015).

43. See http://www.imdb.com/title/tt1285016/?ref_=fn_al_tt_1 (last visited Feb. 22, 2016). 
the fic is close to the truth except that they remain actors. ${ }^{44}$ Neither of them has a child in real life, adopted or otherwise, nor are they in a relationship with each other. ${ }^{45}$

"The Social Network" takes liberties with its stories, but it purports to provide a mostly true demonstration of the facts behind the invention of Facebook. In the end, Mark ends up with a very successful corporation, basically estranged from Eduardo. ${ }^{46}$ While there is some debate about the veracity of some of the movie's moments, the broad strokes appear to follow the basic outline of the Facebook story. ${ }^{47}$ In this, "The Social Network" is like most mainstream RPF: It contains moments of fictionalization but is mainly based around truth.

Online RPF differs from mainstream RPF in that it subverts this balance: It contains some moments of truth but is mainly based around fictionalization. Nor does it pretend otherwise. "It's clearly labeled as fiction; not presented as truthful. ${ }^{, 48}$ It is, after all, called real person fiction, as opposed to more mainstream stories about celebrities that frequently tout being "based on a true story." "RPFers consciously declare their writing to be fictional. RPF writers clearly separate their stories from rumors, even when their stories are immediate responses to real-life events." ${ }^{, 49}$ Online RPF frequently uses some reality as a jumping-off point to construct the story (Eisenberg and Garfield are both actors who give interviews in which they appear to like each other), but these online stories then gleefully leap into the realm of the fantastic.

\section{The Legality of OnLine Stories About Celebrities}

As the frequent controversies discussed supra indicate, the initial kneejerk reaction of many people toward fanfiction RPF is negative, with many people finding it creepy, disturbing, and inappropriate. However, that doesn't necessarily mean the stories are illegal. Indeed, the law protects much speech that is creepy and/or disturbing to some segment of the population, and, also, arguably inappropriate.

Online fiction about celebrities is actually protected in the same way stories about celebrities have been protected with approval for years. As has just been discussed, the only appreciable difference between the online stories and the mainstream stories is the online stories' aggressive fictionality. But courts have protected the rights of mainstream real-people storytellers to add dramatic embellishments to their stories when they need

44. See moogle62, supra note 6 .

45. Id.

46. The Social Network, IMDB, http://www.imdb.com/title/tt1285016/?ref_=fn_al_tt_1 (last visited Feb. 22, 2016).

47. Id.

48. Trinity, supra note 14 .

49. Kristina, supra note 16; winterlive, supra note 29 ("we make thing up based on real events"). 
Journal of Law, Technology \& the Internet $\cdot$ Vol. $7 \cdot 2016$

When Real People Become Fictional

to. $^{50}$ The general attitude has been an acknowledgment that you need to change the truth sometimes to tell a good story and consumers of stories understand that. Online fiction about celebrities changes truth in the service of a good story to a different degree, but it is not of a different kind than other forms of story-telling that have traditionally been protected. ${ }^{51}$

This Section examines several different legal regimes under which online fiction about celebrities might be attacked and concludes that these online stories can survive all possible attacks. There is no recourse to copyright or trademark law and neither do privacy or publicity rights threaten the stories. Indeed, under current precedent, the aggressive fictionality that is the only difference between these online stories and other more mainstream forms of storytelling renders the online stories even more protected from legal liability than the Oscar-nominated movies.

\section{A. The Inapplicability of Copyright Law}

Online fiction about celebrities lives in the same pockets of the Internet as fanfiction: the phenomenon of writing stories about other people's stories. "Fanfiction" is like "Pride and Prejudice and Zombies." It's taking fictional Elizabeth Bennet and fictional Fitzwilliam Darcy and moving them from their Regency England setting into a Regency England full of zombies. $^{52}$ Online fiction about celebrities, meanwhile, is more like "Abraham Lincoln, Vampire Hunter." 53 There might be an impulse to lump that together with "Pride and Prejudice and Zombies," the same way that fanfiction and fiction about celebrities show up in the same places online frequently and are sometimes written by the same people. ${ }^{54}$ However, Abraham Lincoln was a real person, not a fictional invention like Elizabeth Bennet and Fitzwilliam Darcy.

This is an important distinction legally because the field of law usually consulted to evaluate whether a given online story is permissible or not is copyright. However, copyright grants people ownership over their fictional creations. It is a long-standing copyright doctrine that facts are not copyrightable. ${ }^{55}$ A celebrity cannot stop other people from telling stories

50. See Sloan, supra note 29.

51. See id., Comment to Compartmentalization and RPF, That Which AMUSES THE CAT (Dec. 10, 2007, 9:28 PM), http://fairestcat.livejournal.com/449918.html; mandy_croyance, Comment to Compartmentalization and RPF, THAT WHICH AMUSES THE CAT (Dec. 11, 2007, 6:39 AM), http://fairestcat.livejournal.com/449918.html ("In the end, RPF is no different than historical fiction about public figures and probably even better than the movies which disclaim 'based on a true story'.").

52. See Seth Graham Smith, Pride and Prejudice and Zombies, (2009).

53. See Seth Graham Smith, Abraham Lincoln: Zombie Hunter (2011).

54. See, e.g., Steiner, supra note 37 (lumping online stories about celebrities in with fanfiction without further discussion).

55. See Jordan M. Blanke, Note, Frank Miller's Sin City College Football: A Game to Die for and Other Lessons about the Right of Publicity and Video Games, 72 WASH. \& LeE L. ReV. 379, 392 (Winter 2015); Tushnet, supra note 34, at 196 
about them because they somehow "own" those facts. If they could, unauthorized biographies and websites like Wikipedia would be in real trouble.

The conclusion reached during a legal analysis of traditional fanfiction is generally that it is acceptable if copyright's doctrine of fair use says that it is (always a dubious and unpredictable undertaking). Because online stories about celebrities don't implicate copyright, however, they have no such legal Sword of Damocles hanging over their head. In fact, to the extent that the stories are creative works, any copyright involved would vest in the writer, not the celebrity, a fact that some fanfiction RPF writers have seemed to intuitively grasp. ${ }^{56}$

An argument might be raised that celebrities are frequently viewed and treated as carefully crafted fictional characters and not real people at all. ${ }^{57}$ Courts have appeared susceptible to the conflation of reality and fiction, sometimes treating celebrities as if they are in fact equivalent to the characters they play. ${ }^{58}$ It may make some sense, therefore, that many fans have sought to defend their practice of online stories about celebrities by alleging that celebrities are actually fictional and that their stories are therefore the equivalent of the more widely-accepted (in fandom circles) phenomenon of fanfiction. ${ }^{59}$

However, shifting online stories about celebrities to be closer to traditional fanfiction is actually the wrong ground on which to defend

(" $[\mathrm{N}]$ ames and likenesses are uncopyrightable.... Facts are not copyrightable ....”).

56. See Trinity, supra note 14 (noting that "several writers said that they wouldn't remove their stories from the web, even if asked to do so by the Real Person" because "[t]he stories belong to the writer . . . not to the celebrity").

57. See, e.g., winterlive, Comment to [ an inspired word will come across your tongue ], LiveJournal (Sept. 14, 2007, 4:34 AM), http://winterlive.livejournal.com/389407.html; winterlive, supra note 29 (referring to online stories about celebrities as "a radical interpretation of the text" in the same way traditional fanfiction is).

58. See Alex J. Berger, Righting the Wrong of Publicity: A Novel Proposal for a Uniform Federal Right of Publicity Statute, 66 HASTINGS L.J. 845, 847 (Apr. 2015).

59. See kuwsi_dilla, Comment to RPS: Another Persepctive [sic], FAnTHROPOLOGY THE STUDY OF FANDOM (Mar. 22, 2005, 9:27 PM), http://fanthropology.livejournal.com/33447.html ("I'm borrowing there [sic] 'persona' just like FPS folks borrow characters from books, movies, anime, and tv shows."); Christian, supra note 19; Kristina, supra note 1626; zubird, RPF?!, FANTHROPOLOGY - THE STUDY OF FANDOM (Aug. 11, 2005, 4:25 PM), http://fanthropology.livejournal.com/117158.html ("i've [sic] never really believed that celebrities are real people as such ...."); zubird, Comment to RPF?!, FAnTHROPOlOGY - THE StUdy OF FANDOM (Aug. 11, 2005, 10:28 PM), http://fanthropology.livejournal.com/117158.html; superkupos, Comment to RPF?!, FAnTHRopology - The Study of FAndom (Aug. 11, 2005, 10:20 PM), http://fanthropology.livejournal.com/117158.html; azurejay, Comment to Compartmentalization and RPF, THAT WHICH AMUSES THE CAT (Dec. 10, 2007, 5:01 PM), http://fairestcat.livejournal.com/449918.html; mandy_croyance, Comment to Compartmentalization and RPF, THAT WHICH AMUSES THE CAT (Dec. 11, 2007, 6:55 AM), http://fairestcat.livejournal.com/449918.html. 
Journal of Law, Technology \& the Internet · Vol. $7 \cdot 2016$

When Real People Become Fictional

them. Traditional fanfiction suffers from the vagaries of copyright law. Online stories about celebrities are freed from all of that. Rather than causing their existence to be questioned more intensely, the fact that online stories about celebrities are about real people is actually the fact that most protects its legality under copyright law. ${ }^{60}$ Moreover, the argument that the celebrities in these online stories are fictional ignores the fact that all of these stories take as their starting point a certain number of incontrovertible facts about the real person's life.

Courts may seem to wish to give celebrities some rights in the fictional characters they play, ${ }^{62}$ but this is notably different than giving celebrities rights in themselves as fictional creations. So, for instance, the Ninth Circuit in Wendt v. Host International recognized some injury on the part of actors when robots were created that resembled the characters the actors were famous for portraying - and thus, necessarily, the actors themselves. But this right was rooted in publicity rights, not copyright, and distinguished the fictional nature of the characters from the real nature of the actors themselves. ${ }^{63}$

There is some limited dicta supporting the idea that a celebrity's public persona to be fictional. In a case involving a depiction of Vanna White as a futuristic robot, ${ }^{64}$ the Ninth Circuit (again) noted that Vanna White might be considered "a copyrightable character in her own right." 65 This could open the door for celebrities to begin claiming copyright in their own personas. However, like the Wendt case, the Vanna White decision

60. See Trinity, supra note 14.

61. See Sandy Keane, All About the Pairings, or From the Outside In, ThE FAnFIC SYMPOSIUM (Oct. 1, 2002), http://www.trickster.org/symposium/symp105.html ("Writing Justin Tumberlake, I have ten solid facts . . .."); Kristina, supra note 16; FairestCat, Compartmentalization and RPF, THAT WHICH AMUSES THE CAT (Dec. 10, 2007, 10:02 AM), http://fairestcat.livejournal.com/449918.html; winterlive, [ an inspired word will come across your tongue ], LIVEJOURNAL (Sept. 13, 2007, 7:04 PM), http://winterlive.livejournal.com/389407.html; phaballa, Comment to [ an inspired word will come across your tongue ], LIVEJOURNAL (Sept. 14, 2007, 1:17 AM), http://winterlive.livejournal.com/389407.html.

62. See Tushnet, supra note 34, at 204; Wendt v. Host Int'l, Inc., 125 F.3d 806, 810 (9th Cir. 1997) (recognizing the implication of some rights of actors when robots were created to resemble the fictional characters the actors played).

63. See Wendt, 125 F.3d at 811 (focusing on "the right to control the commercial exploitation of his or her likeness by portraying a fictional character"). Even with this limitation, commentators have expressed concern that rulings like this "essentially wrest[] control of characters away from the copyright holders and give[] control of the characters to the actors who first portrayed the roles," with the result of "severely limit[ing] the rights of creators of fictional characters." Jennifer E. Rothman, Copyright Preemption and the Right of Publicity, 36 U.C. DAVIS L. REV. 199, 212 (Nov. 2002); see also White v. Samsung Elecs. Am., Inc., 971 F.2d 1395, 1405 (9th Cir. 1992) ("To say that Vanna White may bring an action when another blond female performer or robot appears on such a set as a hostess will, I am sure, be a surprise to the owners of the show.") (Alarcon, J., concurring in part and dissenting in part).

64. See White, 971 F.2d at 1399.

65. Id. at 1397. 
vindicated this theoretical copyright interest through the realm of trademark and publicity rights rather than using copyright. ${ }^{66}$

Actually providing a copyright interest in a celebrity's personhood would radically shift the entire body of copyright law. Centuries-old doctrines regarding ownership of facts, writings of biographies, registration requirements, and tangible media would all have to be vacated. The Ninth Circuit's retreat from copyright as a basis for its decision in White was the right choice. Celebrities are treated as people for purposes of all other laws, such as taxation, torts, and crimes. They should be treated as people for purposes of copyright law, too.

Therefore, to stop people from telling these online stories about celebrities, a theory of law other than copyright is needed. The debates that people have been having over fanfiction for quite some time have no application to debates about online stories about celebrities. There simply is no copyright implication. Online stories about celebrities are something different that require a different legal lens.

\section{B. The Inapplicability of Trademark Law}

One possible legal recourse is the trademark laws under the Lanham Act. This is the reason why celebrities like Taylor Swift trademark their lyrics, ${ }^{67}$ for the added extra protection trademark law can provide where copyright law might otherwise fail. However, there are difficulties in using trademark law to combat stories.

\section{Issues with Using Infringement and False Endorsement Law}

First, a trademark must identify the holder as a source of a good or service. ${ }^{68}$ Taylor Swift can get a trademark on her lyrics for the purposes of identifying her as a source of entertainment services like singing and touring and even for the purposes of identifying her as a source of merchandise, but it is tricky to state that the public recognizes her as a source of telling stories about herself. Courts have noted that a celebrity's trademark rights in themselves as purveyors of services has been considered to be very narrow. ${ }^{69}$

Even if Taylor Swift could be identified as the source of telling stories about herself, another difficulty is that trademark law requires a likelihood

66. See id. at 1400 .

67. See http://www.rollingstone.com/music/news/taylor-swift-trademarks-this-sickbeat-and-other-1989-phrases-20150128 (last visited Feb. 22, 2016).

68. See ETW Corp. v. Jireh Pub'g, Inc., 332 F.3d 915, 922 (6th Cir. 2003) ("Not every word, name, symbol or device qualifies as a protectable mark; rather, it must be proven that it performs the job of identification, i.e., to identify one source and to distinguish it from other sources. If it does not do this, then it is not protectable as a trademark.") (citing J. THOMAS MCCARTHY, MCCARTHY ON TRADEMARKS AND UNFAIR COMPETITION, § 3:1 (2002)).

69. See Tushnet, supra note 34, at 183;ETW, 332 F.3d at 922. 
Journal of Law, Technology \& the Internet · Vol. $7 \cdot 2016$

When Real People Become Fictional

of confusion about the source of a particular good or service. ${ }^{70}$ In false endorsement situations, such as celebrity endorsements of products, such confusion may occur, ${ }^{71}$ and, indeed, the Lanham Act seems most at home in situations where the celebrity has been deceptively presented as a spokesperson for a brand. ${ }^{72}$ Courts have found this risk to be minimal in situations where only the celebrity's name is referenced in terms that do not imply endorsement. ${ }^{73}$ The use of celebrities' names in online stories would not seem to leave the impression of endorsement, given the familiarity of most consumers with situations where stories are told about celebrities without their endorsement.

Even in situations where courts have found Lanham Act violations based on use of a celebrity's persona, though, courts have been especially convinced by a "tendency to deceive." stories presents as so aggressively fictional. Moreover, the customary trademark analysis of the similarity between the celebrity and the depiction of the celebrity could lead to messy results in these stories where the celebrity becomes a college student, a barista, or a zombie fighter. ${ }^{75}$

Courts have been even more skeptical about the presence of this confusion in situations where celebrities are trying to assert trademark rights in themselves to prevent creative works depicting them. ${ }^{76}$ Applying courts' reasoning to online stories about celebrities, an online story about Taylor Swift dating Lady Gaga will probably not be understood by

70. See ETW, 332 F.3d at 926.

71. See Wendt, 125 F.3d at 814 (" $[\mathrm{T}]$ he potential exists that in the future Ratzenberger's endorsement of other beers would be confused with his alleged endorsement of the beers sold at Host's bars.”); Facenda v. N.F.L. Films, Inc., 542 F.3d 1007, 1024 (3rd Cir. 2008).

72. See Allen v. Nat'l Video, Inc., 610 F. Supp. 612, 626 (S.D.N.Y. 1985); ETW, 332 F.3d at 925. In those situations, at least one commentator has suggested, the Lanham Act functions as "the federal equivalent of the right of publicity." ETW, 332 F.3d at 924 (citing Bruce P. Keller, The Right of Publicity: Past, Present, and Future, 1207 PLI CORP. LAW \& PRAC. HANDBOOK 159, 170 (Oct. 2000)).

73. See C.B.C. Dist'n \& Mktgs, Inc. v. Major League Baseball Advanced Media, L.P., 443 F. Supp. 2d 1077, 1087 (E.D. Mo. 2006) ("Unlike cases where there was an appropriation of likeness to create the impression that a famous person endorsed a product, CBC's use of players' names in no way creates an impression that players endorse CBC's fantasy game." (emphasis in original)).

74. Allen, 610 F. Supp. at 626.

75. See id. at 627 (noting the court must "consider whether the [celebrity depiction] is sufficiently similar to [the celebrity] to create ... a likelihood [of confusion]" (emphasis in original)).

76. See ETW, 332 F.3d at 922 ("No reasonable person could believe that merely because these photographs or paintings contain [the celebrity's] likeness or image, they all originated with [the celebrity]."); see also White, 971 F.2d at 1406 (Alarcon, J., concurring in part, dissenting in part) ("In this matter, the consumer is confronted with two entities. One is Vanna White. The other is a robot. No one could reasonable confused the two."). Even White, otherwise a high water mark of receptiveness to celebrities trademarking their personas, emphasized that the use of the fame must be "closely related" to the reasons the celebrity is famous. $971 \mathrm{~F} .2 \mathrm{~d}$ at 1400 . It is unclear how "closely related" stories would be where the celebrity is depicted in different environments or otherwise untruthfully. 
consumers as coming from Taylor Swift, even if consumers might mistakenly believe the story to be true. Trademark law exists to protect only the former kind of confusion. Where it is absent, trademark law has no place. ${ }^{77}$ The use of disclaimers ${ }^{78}$ and the aggressive fictionality of these online stories about celebrities neuters the threat of this type of consumer confusion.

Moreover, trademark law does not exist in a vacuum but must interact with the First Amendment. Seeking to apply trademark law to online stories about celebrities is the use of trademark law to silence a creative work, and courts have only considered such action "where the public interest in avoiding consumer confusion outweighs the public interest in free expression." ${ }^{, 79}$ Courts are reluctant to enjoin creative speech even where some likelihood of confusion exists: ${ }^{80}$ "[W] here the defendant has articulated a colorable claim that the use of a celebrity's identity is protected by the First Amendment, the likelihood of confusion test is not appropriate because it fails to adequately consider the interests protected by the First Amendment." 81 Therefore, the likely absence of any real confusion is therefore even more problematic for celebrities seeking to use such slight evidence to stifle speech. Even if some number of people believe aggressively fictional stories about celebrities online to be true, it would probably not be sufficient to overcome the protection of creative speech. ${ }^{82}$

77. See ETW, 332 F.3d at 926 ("[T] he controlling issue is likelihood of confusion.").

78. See Sloan, supra note 29; sinensis, this is not the post you're looking for (July 28, 2003, 11:47 AM), http://sinensis.dreamwidth.org/91606.html\#cutid1; nopseud, supra note 17; angrybabble, Comment to RPF?!, FANTHROPOLOGY - THE STUDY OF FANDOM (Aug. 11, 2005, 10:47 PM), http://fanthropology.livejournal.com/117158.html; pensnest, Comment to RPS and privacy, LIVEJOURNAL (Apr. 29, 2007, 8:34 AM), http://ignazwisdom.livejournal.com/2007/04/29/; ignazwisdom, Comment to RPS and privacy, LiveJournal (Apr. 29, 2007, 9:22 PM), http://ignazwisdom.livejournal.com/2007/04/29/; druidspell, Comment to RPS and privacy, LIVEJOURNAL (Apr. 29, 2007, 7:26 PM), http://ignazwisdom.livejournal.com/2007/04/29/; msilverstar, Comment to RPS and privacy, LiveJournal (Apr. 29, 2007, 8:12 PM), http://ignazwisdom.livejournal.com/2007/04/29/; queenofhell, some anti-RPS arguments that I do not understand, LiveJournal (Mar. 24, 2005, 11:38 PM), http://queenofhell.livejournal.com/2005/03/24/; turnyourankle, this is what $i$ do when $i$ should be cleaning, LIVEJOURNAL (Dec. 8, 2007, 3:56 PM), http://turnyourankle.livejournal.com/2007/12/08/; Emily_shore, supra note 30; kalpurna, Comment to Just beautiful, LiveJournal (Jan. 4, 2008, 10:09:52 PM), http://kalpurna.livejournal.com/2008/01/04/.

79. Rogers v. Grimaldi, 875 F.2d 994, 999 (2nd Cir. 1989).

80. See ETW, 332 F.3d at 926; Rogers, 875 F.2d at 1001.

81. $E T W, 332 \mathrm{~F} .3 \mathrm{~d}$ at 926.

82. See id. at 937. 


\section{Issues with Using Dilution Law}

Likelihood of confusion is not required under a trademark dilution analysis, ${ }^{83}$ so perhaps celebrities might try to use dilution law to vindicate their interests. Celebrities, after all, have some level of fame and recognition among the general U.S. population, and the presence of online stories about them might blur or tarnish their distinctiveness - all that is required for a dilution case. ${ }^{84}$

Dilution law still must contend with the First Amendment, however, and dilution is specifically an area where courts have been especially protective of First Amendment purposes such as parody, with a parody defense explicitly mentioned in the dilution statute. ${ }^{85}$ As will be discussed in the next section, infra, many online stories about celebrities could qualify for as parodies. It is therefore not obvious that dilution law ensures the illegality of all online stories about celebrities. In fact, it might be especially powerless against the most damaging stories that make the most fun of celebrities - not an outcome it seems celebrities would want.

\section{The Inapplicability of Privacy Rights}

Privacy rights are those laws that stop people from saying anything they want about another person, regardless of whether people can own the facts of their own lives under copyright or are considered the source of these stories under trademark. You may not own the facts of your life, but you can use privacy rights to help protect yourself from having those private facts splashed all over public places. There are a variety of state law privacy rights, such as unreasonable intrusion on personal solitude, public disclosure of true but embarrassing facts, defamation, intentional infliction of emotional distress, and presentation of people in a false light in the public eye. Private individuals have recourse to all of these torts to try to protect the private facts about their lives. They can't claim copyright, so they get privacy rights instead. However, as with copyright and trademark laws, there are challenges in trying to apply privacy rights to online stories about celebrities.

\section{The Lack of Privacy Violation}

Part of the problem of trying to apply privacy rights to online stories about celebrities is that, in these aggressively fictional stories, it's hard to argue that anything private is being shared at all. If you're writing a story about Harry Styles from One Direction going to college, other than his name, what he looks like, and maybe a few quotes from interviews he's

83. 15 U.S.C. $\$ 11251127$.

84. 1545 U.S.C. $\S 1125(\mathrm{c})$.

85. 1545 U.S.C. $\S 1125(\mathrm{c})$. 
Journal of Law, Technology \& the Internet · Vol. $7 \cdot 2016$

When Real People Become Fictional

given, you haven't taken anything from him. None of the stuff you have taken is private. ${ }^{86}$ One fan has summarized,

"[T]he details we know about people we write RPS about are not, in fact, details of their 'private life'-we're not interviewing ex-girlfriends or digging through their trash or taking photos through their living room windows. The details we use in fic are the ones that they willingly chose to share with the general public in interviews and onstage ...."87

It's hard to call such behavior a violation of a privacy right, therefore, as, indeed, the precedent has found: "No one has the right to object merely because his name or his appearance is brought before the public, since neither is in any way a private matter and both are open to public observation." 88

This is, in fact, a situation where one might expect the law to be harsher on the more mainstream forms of fiction about people, like the Oscar-nominated movies supra. There, one could make an argument that there's something private being exposed about the marriage of Stephen Hawking, or the personal life of Alan Turing, or the friendship between Mark Zuckerburg or Eduardo Saverin, or the inner struggles of a king. These stories are attempting to show you something very private about a person. That's the entire point of them. If the actual sharing of private details in mainstream stories about real people is legally acceptable from a

86. See Kristina, supra note 16 ("[T]he public persona is the entirety of RPF's canon."); luxshine, Comment to RPS and privacy, LiVEJouRnAL (Apr. 29, 2007, 4:10 PM), http://ignazwisdom.livejournal.com/2007/04/29/ ("All our 'canon' is what they chose to make public, by interviews, concerts, radioshows [sic]. There's nothing we RPFers ... know that a regular fan can't know, so it's not as if we were rumaging [sic] through their trashcans."); queenofhell, supra note 78; stele3.insanejournal.com, Comment to Compartmentalization and RPF, THAT WHICH AMUSES THE CAT (Dec. 10, 2007, 5:58 PM), http://fairestcat.livejournal.com/449918.html ("[W]e know their public personas and whatever details about their lives that they're willing to share with us."); fairestcat, Comment to Compartmentalization and RPF, THAT WHICH AMUSES THE CAT (Dec. 10, 2007, 7:19 PM), http://fairestcat.livejournal.com/449918.html; fairestcat, Comment to Compartmentalization and $R P F$, THAT WHICH AMUSES THE CAT (Dec. 10, 2007, 9:20 PM), http://fairestcat.livejournal.com/449918.html ("I think it's important to recognize... those publicly available facts: dietary restrictions, pets, where (as in the city) people live, what details of their lives and the pasts they choose to share publicly...."); queenofhell, Comment to Compartmentalization and RPF, THAT WHICH AMUSES THE CAT (Dec. 11, 2007, 6:42 AM), http://fairestcat.livejournal.com/449918.html; wendelah1, Comment to RPF - just stop doing it, KHYBER (Feb. 19, 2009, 8:31 PM), http://thatkhyber.livejournal.com/2009/02/18/.

87. queenofhell, Comment to Compartmentalization and RPF, THAT WHICH AMUSES THE CAT (Dec. 11, 2007, 6:42 AM), http://fairestcat.livejournal.com/449918.html); see also winterlive, supra note 29 ("[O]ur guys give interviews, they are reported on, and we take what we know of them and the world they live in, and we create a fiction that's believable.").

88. Matthews v. Wozencraft, 15 F.3d 432, 439 (5th Cir. 1994) (quoting RestatemENT $\S 625 \mathrm{C}$, cmt. d); see also Dora v. Frontline Video, Inc., 15 Cal. App. 4th 536, 545 (1993) (noting that "public affairs" are "related to real-life occurrences"). 
Journal of Law, Technology \& the Internet $\cdot$ Vol. $7 \cdot 2016$

When Real People Become Fictional

privacy rights viewpoint, the sharing of no private details in aggressively fictional online stories about them must also be acceptable.

\section{The Challenges of Applying Privacy Rights to Celebrities}

The other wrinkle in applying privacy rights to online stories about celebrities is that privacy rights do not apply as broadly to celebrities as they do to regular individuals, because celebrities live more public lives. The vast majority of online stories about celebrities revolve around very public celebrities, as it is the celebrity engagement with fans and the press that is used to shape these stories. ${ }^{89}$ It is, again, the more mainstream forms of stories about real people that would raise legal eyebrows here. It is those stories that tend to focus on those individuals who might be considered more private, like murder victims or victims of natural disasters. If those mainstream forms of expression have been held not to violate the privacy rights of those essentially private individuals, it's hard to see how online stories about far more public people would be judged more harshly. ${ }^{90}$

Because the online stories are about celebrities, privacy rights require actual malice on the part of the writer of the story to find a privacy right violation. ${ }^{91}$ Actual malice requires that a statement be "knowingly false or... published with reckless disregard for the truth." exaggerated fictionalization is not actionable under privacy rights for more mainstream forms of stories about celebrities, under the theory that no one would believe the exaggerated fictionalization to be true. ${ }^{93}$ People are permitted the use of public materials, even "in fictionalized form."

Likewise, deliberate exaggerated fictionalization should not be actionable for online stories about celebrities. "The test is not whether the story is or is not characterized as 'fiction,' 'humor,' or anything else in the publication, but whether the charged portions in context could be reasonably understood as describing actual facts about the plaintiff or

89. See Kristina, supra note 16 ("[T] around celebrities who provide much canon in forms of extensive media footage.").

90. See Ninth Circuit Tosses Hurt Locker Case, Rothman's RoAdmap to the Right of Publicity (Feb. 17, 2016); Sarver v. Chartier, No. 11-56986 (9th Cir. Feb. 17, 2016).

91. See Comedy III Prods., Inc. v. Gary Saderup, Inc., 25 Cal. 4th 387, 398 (2001); Eastwood v. Super. Ct., 149 Cal. App. 3d 409, 424 (1983).

92. Zacchini v. Scripps-Howard Broad. Co., 433 U.S. 562, 571 (1977); Eastwood, 149 Cal. App. 3d at 424; Matthews, 15 F.3d at 440.

93. See Dara Sloan, Slashers of Silicon Valley, The Fanfic Symposium (Aug. 13, 1999), http://www.trickster.org/symposium/symp8.htm; Hart v. Electronic Arts, Inc., 717 F.3d 141, 174 (3rd Cir. 2013) ("The First Amendment extends protection to biographies, documentaries, docudramas, and other expressive works depicting real-life figures, whether the accounts are factual or fictional.”) (Ambro, J., dissenting); Rosa \& Raymond Parks Institute for Self Development v. Target Corp., No. 15-10880 (11th Cir. Jan. 4, 2016).

94. Matthews, 15 F.3d at 441; see also Hicks v. Casablanca Records, 464 F. Supp. 426 (S.D.N.Y. 1978). 
Journal of Law, Technology \& the Internet · Vol. $7 \cdot 2016$

When Real People Become Fictional

actual events in which she participated. ${ }^{.95}$ So, in a case brought by a beauty pageant contestant against Penthouse based on a story it ran in which a character alleged to have resembled her engaged in gravitationally impossible sexual acts, the court found no violation of privacy rights because the story was simply too implausible to believe:

"The charged potions of the story described something physically impossible in an impossible setting. In these circumstances we must reach the ... conclusion ... that it is simply impossible to believe that a reader would not have understood that the charged portions were pure fantasy and nothing else. It is impossible to believe that anyone could understand that levitation could be accomplished by oral sex before a national television audience or anywhere else. The incidents charged were impossible. The setting was impossible."

Many of the online stories about celebrities contain similar impossible incidents and impossible settings that would be impossible for a reader to believe. Again, this is a situation where one would expect the law to be harsher toward more mainstream forms of storytelling about celebrities. ${ }^{97}$ The fear that someone will believe a false statement is far greater in a mainstream story that otherwise seems factual, true, and believable, than in an outrageous story in which Mark Zuckerberg and Eduardo Saverin are fighting zombies. The odds that anyone takes anything seriously in such a story is very low.

Actual malice requires the setting forth as true something that could be false. " "[T]he concern is with defamatory lies masquerading as truth" or with "nondefamatory lies masquerading as truth." as true that Harry Styles is a college student instead of a singer in a band. ${ }^{100}$ It would be implausible to believe that anyone reading the story would actually think Harry Styles was a secret college student. In fact, the reason that story works is because of the inside joke that Harry Styles is not a college student. In fact, such an understanding is at the heart of the publication of any online story about a celebrity in the fandom context: "[R]ather than trying to convince the reader that their stories are truth, they

95. Pring v. Penthouse Int'l, Ltd., 695 F.2d 438, 442 (10th Cir. 1982).

96. Id. at 443 .

97. See sarken, Comment to Don't think twice, it's all right: ten easy excuses for RPF writers, The ARTist Formerly KnOwn as NARAht (Jan. 17, 2009, 3:51 AM), http://emily-shore.livejournal.com/286793.html

98. See Eastwood, 149 Cal. App. 3d at 426 ("[T]he deliberate fictionalization of Eastwood's personality constitutes commercial exploitation, and becomes actionable when it is presented to the reader as if true with the requisite scienter." (emphasis added)).

99. Id. at 425 .

100. See mandy_croyance, Comment to Compartmentalization and RPF, THAT WHICH AMUSES THE CAT (Dec. 11, 2007, 6:39 AM), http://fairestcat.livejournal.com/449918.html. One fan writer actually calls this "the 'absence of malice' clause." Mjules, Comment to Don't think twice, it's all right: ten easy excuses for RPF writers, THE ARTIST FORMERLY KNOWN AS NARAHT (Jan. 14, 2009, 10:55 PM), http://emilyshore.livejournal.com/286793.html. 
are counting on the fact that readers will know that they are not." ${ }^{101}$ "This duality is what RPF thrives on: the writer and reader must simultaneously believe and disavow the "reality' presented by the media." 102 In this holding of simultaneously contradictory fact patterns, online stories about celebrities therefore perfectly fit the paradigm of parody.

Online writers do not write stories about Harry Styles in college hoping to trick people into thinking the celebrity Harry Styles is anything like their Harry Styles. Rather, they are engaging in an obvious (and, in fandom circles, familiar) bit of fictional play. They are possibly using his fame to win their stories some attention, but that is a different possible tort: a publicity right tort.

\section{The Inapplicability of Publicity Rights}

Publicity rights are perhaps the broadest rights implicated by online stories about celebrities ${ }^{103}$ Publicity rights are a matter of state law, ${ }^{104}$ both statutory and common, ${ }^{105}$ which make them challenging in the context of inherently nationwide behavior like the posting of online stories about celebrities. However, some generalizations can be drawn based on the precedents that have been assembled, especially in California, where, unsurprisingly, publicity rights tend to be of more central importance than in other less-celebrity-centric jurisdictions.

Publicity rights came into being mainly in a 1977 Supreme Court case called Zacchini that found that celebrities were allowed to protect their acts from commercial misappropriation. In that case, there was a man who was a human cannonball. A local news crew filmed his entire act of shooting himself out of a cannon and showed it on the news. The man sued for this and won. The news crew protested that this was surely a violation of their First Amendment right to report the news. The Supreme Court stated that it was permissible for the state to consider the news crew's actions a violation of the man's publicity right, because if the news could do what it had done, then the man would never make any money and therefore people would be discouraged from developing future acts of interest like the human cannonball act at issue in the case. ${ }^{106}$

The right of publicity exists somewhere between the tort protection of privacy rights and the intellectual property protection of copyright and trademark. ${ }^{107}$ The underlying policy justifying the right has been hotly

101. Sinensis, supra note 78 (emphasis in original); see also countefeitcoin, Comment to RPS and privacy, LiveJournal (Apr. 29, 2007, 18:25 PM8:34 AM), http://ignazwisdom.livejournal.com/2007/04/29/.

102. Kristina, supra note 16.

103. See Hart, 717 F.3d at 158.

104. See ETW, 332 F.3d at 928; Rothman, supra note 90, at 203, 244.

105. See Kirby v. Sega of Am., Inc., 144 Cal. App. 4th 47, 55 (2006); ETW, 332 F.3d at 954 (Clay, J., dissenting); Comedy III, 25 Cal. 4th at 391.

106. Zacchini, 433 U.S. 562.

107. See Tushnet, supra note 34, at 195; Zacchini, 433 U.S. at 573. 
Journal of Law, Technology \& the Internet · Vol. $7 \cdot 2016$

When Real People Become Fictional

debated through the years, ${ }^{108}$ but the end result is that they provide celebrities with a modicum of control over public discourse about them. ${ }^{109}$ They are not, however, rights rooted in misrepresentation or defamation concerns the way privacy rights torts are. ${ }^{110}$ Rather, publicity rights are economic in nature. "[F]amous people often receive money for their endorsement of a product, and if they cannot exclusively assign this right, they might not otherwise receive payment for services as celebrity advertisers." 111 As the Zacchini case made clear, publicity rights are intended to protect one's livelihood as a "hot commodity," not one's feelings. ${ }^{112}$

Publicity rights concern the appropriation of one's name and likeness for commercial purposes. ${ }^{113}$ Traditionally, they were targeted toward controlling use of one's image in advertising. ${ }^{114}$ The right used to be used only when it came to the celebrity's name or likeness, such as a picture of the celebrity's face being used to endorse wrinkle cream, but it has been expanded to include things like a celebrity's distinctive voice. ${ }^{115}$ Indeed, anything that might remind the public of a celebrity can be a violation of the celebrity's publicity right. ${ }^{116}$ In White, it was the image of a robot in an evening gown wearing a blonde wig, standing by some lighted tiles that called to mind Wheel of Fortune. ${ }^{117}$

108. See Berger, supra note 58, at 850-51; Redish \& Shust, supra note 33, at 1455; Allison Hollows, Who Owns the Athlete?: The Application of the Transformative Use Test in the Right of Publicity Context, 45 SETON Hall L. Rev. 285 (2015); C.B.C., 443 F. Supp. 2d at 1089-90.

109. See Redish \& Shust, supra note 33, at 1447.

110. See Doe v. TCI Cablevision, 110 S.W.3d 363, 372 (Mo. 2003); Mark S. Lee, Agents of Chaos: Judicial Confusion in Defining the Right of Publicity-Free Speech Interface, 23 LoY. L.A. ENT. L. REV. 471, 491 (2003); Zacchini, 433 U.S. at 573.

111. Berger, supra note 58, at 849; see also Matthews, 15 F.3d at 437-38 ("Protecting one's name or likeness from misappropriation is socially beneficial because it encourages people to develop special skills, which then can be used for commercial advantage. Associating one's goodwill with a product transmits valuable information to consumers. Without the artificial scarcity created by the protection of one's likeness, that likeness would be exploited commercially until the marginal value of its use is zero.").

112. See Allen, 610 F. Supp. at 621; C.B.C., 443 F. Supp. 2d at 1090 ("The right to publicity protects pecuniary, not emotional, interests." (quoting Ventura v. Titan Sports, Inc., 65 F.3d 725, 730 (8th Cir. 1995))); Zacchini, 433 U.S. at 573.

113. See Berger, supra note 58, at 849; C.B.C., 443 F. Supp. 2d at 1084; Rothman, supra note 90, at 203; Comedy III, 25 Cal. 4th at 403.

114. See Tushnet, supra note 34, at 200-01; Facenda, 542 F.3d at 1032 ("It is targeted at endorsements, not the full universe of creative works."); C.B.C., 443 F. Supp. 2d at 1087; Matthews, 15 F.3d at 439 ("Only the use of an individual's identity in advertising infringes on the persona." (quoting George M. Armstrong, Jr., The Reification of Celebrity: Persona as Property, 51 LA. L. REV. 443, 467 (1991))); see also Lee, supra note 105 , at 488.

115. Midler v. Ford Motor Co., 849 F.3d 460 (9th Cir. 1988).

116. See Rothman, supra note 90, at 206, 222, 225; White, 971 F.2d at 1398; see also $i d$. at 1403 (Alarcon, concurring in part and dissenting in part).

117. See 971 F.2d at 1399; see also Wendt, 125 F.3d at 810. 
Journal of Law, Technology \& the Internet · Vol. $7 \cdot 2016$

When Real People Become Fictional

Publicity rights have been on a continual trajectory of expansion, ${ }^{118}$ so courts have not limited the application of the rights strictly to the advertising arena. ${ }^{119}$ Whereas the Zacchini decision could be described as "a kind of anti-bootlegging rule," virtually every instance where a celebrity's name is mentioned. ${ }^{121}$ In addition, although publicity rights are given only to celebrities, ${ }^{122}$ the definition of celebrity has also continued to expand. ${ }^{123}$ Celebrities now include reality television stars and social media mavens. ${ }^{124}$ Indeed, one court has mused that the word "celebrity" may be losing meaning as a gatekeeper to publicity rights. ${ }^{125}$ For instance, one court suggested that every person could be considered a celebrity in the context of their circle of friends on Facebook. ${ }^{126}$

California has applied its publicity rights most expansively, ${ }^{127}$ with some criticism from California judges on that front. ${ }^{128}$ Still, even considering the most liberal publicity right precedents, online stories about celebrities can survive the arguments launched against them.

\section{The Operation of the First Amendment}

Publicity rights can result in the stifling of speech at the core of First Amendment creativity, ${ }^{129}$ so courts can be hesitant to apply them, ${ }^{130}$ calling

118. See Rothman, supra note 90, at 243-44, 265.

119. See Eastwood, 149 Cal. App. 3d at 419; Rothman, supra note 90, at 225.

120. Tushnet, supra note 34, at 194.

121. See id.

122. See Berger, supra note 58, at 849 ("In response to the limitations on the right of privacy, William Prosser outlined the modern right of publicity ...."); id. at 852 ("The courts were primarily concerned with whether companies or individuals used a celebrity's likeness to sell products without the celebrity's authorization").

123. See Kayla Brandon, I Shared A Candid Photo Between My Grandma And Me. Then I Saw An Ad That Left Me Shocked, LIFT.

124. See Redish \& Shust, supra note 33, at 1457 ("Achieving celebrity today can be as much about serendipity as it is about labor.").

125. See Fraley v. Facebook, 830 F. Supp. 2d 785, 808 (N.D. Cal. 2011) ("In a society dominated by reality television shows, YouTube, Twitter, and online social networking sites, the distinction between a 'celebrity' and a 'non-celebrity' seems to be an increasingly arbitrary one.").

126. See id. at 809.

127. See Berger, supra note 58, at 859 (noting that "New York's right of publicity is much more limited and provides greater First Amendment protection to artistic works than California's law").

128. See White, 971 F.2d at 1403 (Alarcon, concurring in part and dissenting in part).

129. See Rothman, supra note 90, at 206, 243; ETW, 332 F.3d at 931 ("There is an inherent tension between the right of publicity and the right of freedom of expression under the First Amendment."); In re NCAA, 724 F.3d at 1284 (Thomas, J., dissenting) ("In every jurisdiction, any right of publicity must be balanced against the constitutional protection afforded by the First Amendment."); No Doubt v. Activision Publ'g, Inc., 192 Cal. App. 4th 1018, 1029 (2011); Kirby, 144 Cal. App. 4th at 58; Doe, 110 S.W.3d at 375; Sarver.

130. Indeed, publicity rights have been referred to as "a decrepit free speech shackle." Redish \& Shust, supra note 33, at 1447; see also Tushnet, supra note 34, at 205 
Journal of Law, Technology \& the Internet · Vol. $7 \cdot 2016$

When Real People Become Fictional

them "especially vexing." would easily swallow up entire genres like unauthorized biographies. ${ }^{132}$ Courts raised the alarm about this troubling implication of publicity rights early in their genesis: "[I]n proclaiming this new 'right of publicity,' we have created an open-ended and ill-defined force which jeopardizes a right of unquestioned authenticity-free speech."133

Therefore, the First Amendment can step in to protect certain forms of creativity, and this application of the First Amendment is not dictated by commercial considerations. ${ }^{134}$ Just the fact that a profit is being made from an endeavor is not enough to automatically stamp that speech as running afoul of a celebrity's publicity rights. ${ }^{135}$ "Speech is protected even though it is carried in a form that is sold for profit." ${ }^{\text {"36 }}$ Courts protect speech as long as it is not "purely commercial." 137 "Expression ... is not commercial speech if it does not advertise another unrelated product, and speech is not

("[I]t has generally seemed obvious even to proponents of the right [of publicity] that others' interests in freedom of expression trump celebrity interests in controlling non-advertising writing about them, in the absence of defamation or invasion of privacy."); Rothman, supra note 90, at 244 (noting "numerous articles and vociferous dissents suggesting things have gone too far"); ETW, 332 F.3d at 955 (Clay, J., dissenting).

131. Marcinkus v. NAL Pub'g Inc., 138 Misc. 2d 256, 265 (N.Y. Sup. Ct. 1987) (noting that publicity rights are "particularly incompatible with the first amendment" [sic]); see also Ninth Circuit Tosses Hurt Locker Case, Rothman's RoAdMAP TO THE RigHT OF PUBLICITY (Feb. 17, 2016); TM/right of publicity mismatch claims another video game victim, REBECCA TUSHNET'S 43(B)LOG (Sept. 3, 2015).

132. See Martin Luther King, Jr., Ctr. for Social Change, Inc. v. Am. Heritage Prods., Inc., 250 Ga. 135, 151 (1982) (Weltner, J., concurring); Matthews, 15 F.3d at 437; $E T W, 332$ F.3d at 930.

133. Martin Luther King, Jr., Ctr. for Social Change, 250 Ga. at 150 (Weltner, J., concurring). One of the dissents to Zacchini raised the early alarm on this concern: "The Court's holding that the station's ordinary news report may give rise to substantial liability has disturbing implications, for the decision could lead to a degree of media self-censorship.” 433 U.S. at 580 (Powell, J., dissenting).

134. See C.B.C., 443 F. Supp. 2d at 1093 ("A defendant's making a profit does not preclude its receiving First Amendment protection." (emphasis in original)); Noriega v. Activision/Blizzard, Inc., 2014 WL 5930149, *4 (Cal. Oct. 27, 2014) ("Because the video game is transformative, economic considerations are not relevant.").

135. See Comedy III, 25 Cal. 4th at 396 (" [t]he First Amendment is not limited to those who publish without charge.... [An expressive activity] does not lose its constitutional protection because it is undertaken for profit." (quoting Guglielmi v. Spelling-Goldberg Prods., 25 Cal. 3d 860, 868 (1979))).

136. ETW, $332 \mathrm{~F} .3 \mathrm{~d}$ at 924.

137. Berger, supra note 58, at 852; see also C.B.C., 443 F. Supp. 2d at 1094 (defining commercial speech as "expression related solely to the economic interests of the speaker and its audience" (emphasis added) (quoting Cent. Hudson Gas \& Elec. Corp. v. Pub. Serv. Comm'n, 447 U.S. 557, 561 (1980))). And, indeed, "[e]ven pure commercial speech is entitled to significant First Amendment protection." $E T W, 332$ F.3d at 925. 
transformed into commercial speech merely because the product at issue is sold for profit." 138

There has been recognition that "fiction writers may be able to more persuasively, more accurately express themselves by weaving into the tale persons and events familiar to their readers," ${ }^{139}$ and should be allowed to do so. "[T] he range of free expression would be meaningfully reduced if prominent persons in the present and recent past were forbidden topics." Nor does the creative work at issue need to rise to some important level of newsworthiness to enjoy this protection; it must merely be "of interest." There is no sliding scale of First Amendment protection depending on "the ... importance of the ideas seeking expression." "T2 "There is no doubt that entertainment, as well as news, enjoys First Amendment protection."

For this reason, blockbuster movies are probably as commercial as an endeavor can get, but blockbuster movies can use the facts of someone's life and not run afoul of publicity rights, ${ }^{144}$ because movies enjoy First Amendment protection. ${ }^{145}$ Likewise artistic prints are not commercial speech because "[t]hey do not propose a commercial transaction." "146 Similarly, the use of celebrities' likenesses on commercially sold services like fantasy sports teams have not been considered commercial speech, despite their central profit-making endeavor, because they use the celebrities to "communicate[] information," not "for the purpose of advertising a product or services." 147 The First Amendment is applicable even though "factual data and historical facts" might be involved in the expression. ${ }^{148}$

138. C.B.C., 443 F. Supp. 2d at 1094; see also Hart, 717 F.3d at 173 (Ambro, J., dissenting) ("That books, newspapers, and magazines are published and sold for profit does not prevent them from being a form of expression whose liberty is safeguarded by the First Amendment." (quoting Joseph Burstyn, Inc. v. Wilson, 343 U.S. 495, 501 (1952))); ETW, 332 F.3d at 925 ("The fact that expressive materials are sold does not diminish the degree of protection to which they are entitled under the First Amendment.").

139. Guglielmi, 603 P.2d at 459-60.

140. Id.

141. Dora, 15 Cal.App.4th 536; Eastwood, 198 Cal. Rptr. 342; Doe v. Gangland Prod., Inc., 730 F.3d 946, 961 (9th Cir. 2013); C.B.C., 443 F. Supp. 2d at 1093 ("Entertainment features receive the same constitutional protection as factual news reports."). The same "consumer interest" blanket protection applies in New York as well. See Redish \& Shust, supra note 33, at 1471.

142. Time, 385 U.S. at 388.

143. Zacchini, 433 U.S. at 578.

144. See Ninth Circuit Tosses Hurt Locker Case, Rothman's RoAdmap to THE Right of Publicity (Feb. 17, 2016); see also Stephano v. News Group Publ'ns, Inc., 474 N.E.2d 580, 585 (N.Y. 1984); Tushnet, supra note 34, at 165; ETW, 332 F.3d at 930.

145. See Tushnet, supra note 34, at 165; Ninth Circuit Tosses Hurt Locker Case, Rothman's Roadmap to the Right OF Publicity (Feb. 17, 2016).

146. ETW, $332 \mathrm{~F} .3 \mathrm{~d}$ at 925.

147. C.B.C., 443 F. Supp. $2 \mathrm{~d}$ at 1095.

148. Id. at 1092 . 
Journal of Law, Technology \& the Internet · Vol. $7 \cdot 2016$

When Real People Become Fictional

Stories are like movies and artistic prints in the pantheon of First Amendment protection they receive. ${ }^{149}$ They do not propose a commercial transaction. Indeed, some commentators have noted that textual creativity is the most protected form of creativity in the publicity rights arena. ${ }^{150}$ The fact that the work is fictional does not matter; all that matters is that the work is not "simply a disguised commercial advertisement for the sale of goods or services." If a blockbuster movie is noncommercial for purposes of publicity rights, then fanfiction RPF should be considered noncommercial, too, even if it exists on a profitable website and even if a publishing company has advanced funds for it. ${ }^{152}$

There might be an argument that these online stories about celebrities do not add a great deal of creative capital to society, but that should not matter to the analysis. ${ }^{153}$ Protecting a form of expression based on its perceived value would result in considerable censorship concerns. Even those fans who hate online stories about celebrities notice this danger, sometimes drawing the line at a blanket prohibition of the genre because of censorship issues. "154 "[T] he right of publicity cannot, consistent with the First Amendment, be a right to control the celebrity's image by censoring disagreeable portrayals." 155 The right of publicity is emphatically "not a right of censorship." " Judges have resisted the idea that there could be "a broad range of seemingly expressive speech that has no First Amendment value," in favor of erring on the side of broader protectiveness of such speech, even in the face of conflicting publicity rights. ${ }^{157}$ A creative work,

149. See Tushnet, supra note 34, at 165; Plaque buildup: Rosa Parks foundation loses publicity case, REBECCA TuSHNET'S 43(B)LOG (Jan. 5, 2016); Ninth Circuit Tosses Hurt Locker Case, Rothman's Roadmap to the Right of Publicity (Feb. 17, 2016).

150. See Tushnet, supra note 34, at 163; see also C.B.C., 443 F. Supp. $2 \mathrm{~d}$ at 1087.

151. Rogers, 875 F.2d at 1004.

152. See Redish \& Shust, supra note 33, at 1485.

153. See, e.g., Frosch v. Grosset \& Dunlap, Inc., 75 A.D.2d 768, 769 ("It is not for a court to pass on literary categories, or literary judgment."); Marcinkus, 138 Misc. $2 \mathrm{~d}$ at 265 ("[T] $\mathrm{T}$ he instant book, whatever its literary merit or ultimate social value, is a work that is entitled to at least some degree of [F]irst [A]mendment protection."); Comedy III, 21 P.3d at 809 ("[V]ulgar forms of expression fully qualify for First Amendment protection.").

154. See Trinity, supra note 14; q sama, Comment to RPS: Another Persepctive [sic], FANTHROPOLOGY - THE STUDY OF FANDOM (Mar. 22, 2005, 7:57 PM), http://fanthropology.livejournal.com/33447.html; see also hederahelix, supra note 15 (“. . . I don't feel that it's fair that I try to impose my personal ethics on a whole group of other people."); nopseud, supra note 17; winterlive, supra note 29; see also Comedy III, $25 \mathrm{Cal}$. 4th at 398 ("Giving broad scope to the right of publicity has the potential of allowing a celebrity to accomplish through the vigorous exercise of that right the censorship of unflattering commentary that cannot be constitutionally accomplished through defamation actions.").

155. Comedy III, 25 Cal. 4th at 403; see also ETW, 332 F.3d at 955 (Clay, J., dissenting).

156. Comedy III, 25 Cal. 4 th at 403.

157. Hart, 717 F.3d at 154 . 
"whatever its literary merit or ultimate social value, is a work that is entitled to at least some degree of [F]irst [A]mendment protection." 158

\section{Aggressive Fictionality, Parodies, and Transformativeness}

Publicity rights have especially protected those situations where a great deal of creativity surrounds the celebrity appropriation. It is not the commercialism that matters; it is whether the work is transformative. ${ }^{159}$ The publicity rights analyses, especially in California, have come to center around "creative transformativeness." 160 This test asks "whether a celebrity likeness is one of the 'raw materials' from which an original work is synthesized, or whether the depiction or imitation of the celebrity is the very sum and substance of the work in question." ${ }^{\text {"61 }}$ If the former situation, then courts conclude that the celebrity's likeness is secondary to the creator's expression in the work in question and protect the work, under the theory that significantly transformative works are "less likely to interfere with the economic interests implicated by the right of publicity." "162 Other tests in other jurisdictions have used different words in an attempt to reach the same result of protecting works that consist mostly of "an expressive comment on or about a celebrity."

The result of this focus on transformativeness is that courts dislike exact portraits of a celebrity. The courts are looking for "something more than a mere celebrity likeness or imitation." ${ }^{164}$ For this reason, a realistic portrait of the Three Stooges has been found to run afoul of publicity rights, ${ }^{165}$ but courts support more outrageous depictions. For instance, a court rejected Jerry Falwell's publicity rights claim against Hustler magazine for its article informing readers that he was engaged in a sexual relationship with his mother. ${ }^{166}$ Likewise, the Winter Brothers singers' case failed against a comic book that included the characters of "the Autumn Brothers, villainous half-worm, half-human offspring born from the rape of their mother by a supernatural worm creature that had escaped from a hole in the ground." 167 The court said that the obvious creativity involved in creating the Autumn Brothers protected the speech, even if they had also been obviously inspired by the Winter Brothers and were meant to invoke them in the illustrations. The court praised the fact that the Autumn Brothers were "fanciful, creative characters." 168

158. Marcinkus, 138 Misc. $2 \mathrm{~d}$ at 265.

159. See Hilton v. Hallmark Cards, 599 F.3d 894, 910 (9th Cir. 2009).

160. See Berger, supra note 58, at 853.

161. Comedy III, 21 P.3d at 809.

162. Hart, 717 F.3d at 159.

163. Doe, 110 S.W.3d at 374; see also Eugene Volokh, Target has right to sell Rosa Parks biographies, commemorative plaque, WASH. PosT (Jan. 4, 2016).

164. Comedy III, 25 Cal. 4th at 391.

165. Id.

166. Hustler Magazine v. Falwell, 485 U.S. 46 (1988).

167. Winter v. DC Comics, 30 Cal. 4th 881 (2003).

168. See No Doubt, 192 Cal. App. 4th at 1033. 
One may try to argue that cases like the Autumn Brothers and Falwell are protected because they are "parodies," which online stories about celebrities are not. But the line between parody and non-parody is notoriously difficult to draw. Not only could some online stories about celebrities easily be considered a parody, as discussed supra, ${ }^{169}$ but courts seem to have been reluctant to import the messy parody label so common in copyright cases to the publicity rights analysis. While the "transformativeness" term may come from copyright's fair use doctrine, ${ }^{170}$ the analysis is otherwise divorced from copyright's standards. ${ }^{171}$ It does not require a parodic purpose and explicitly encompasses a wide variety of transformative works. ${ }^{172}$ The Autumn Brothers comic book depiction was permissible not because of any coherent parodic message but because of how creative it was. ${ }^{173}$ The earthworm-aliens were part of an independent work of art in which celebrities' likenesses simply appeared as one of many elements. ${ }^{174}$ " $[\mathrm{N}]$ ew expression, departing from realism, [is] enough to be transformative, even without a particular meaning or message." "Th5 "The law does not require [a statement,] whether factual or critical or comedic about... the public figure in order to receive First Amendment protection." 176 At any rate, one would not expect celebrities to argue that they prefer vicious, biting, satirical portraits of themselves to fond, affectionate, adoring portraits. ${ }^{177}$

The reliance on transformativeness in publicity right cases has translated into protection of outrageously fictionalized things: The less a work is intended to be a sincere, genuine portrait of the celebrity, the more likely the work will be permissible. ${ }^{178}$ If the work "adds significant creative elements" $" 179$ to a celebrity depiction, then it is considered transformative.

The threshold of how much transformation is enough is a blurry line. ${ }^{180}$ Like the fair use test it is extracted from, it is susceptible to aesthetic

169. See Trinity, supra note 14 ("[T] parodies of themselves ....."); see also afullmargin, Comment to ladysorka, On FBR/MCR Bandom and the Fourth Wall, I DON'T WANT TO WAKE UP (Jan. 6, 2008, 9:11 AM), http://ladysorka.livejournal.com/2008/01/04/.

170. See Hollows, supra note 103, at 306; Comedy III, 25 Cal. 4th at 405; Hart, 717 F.3d at 158; Lee, supra note 105, at 492.

171. See Berger, supra note 58, at 853; Redish \& Shust, supra note 33, at 1474; Comedy III, $25 \mathrm{Cal}$. 4th at 404 ("We conclude that a wholesale importation of the fair use doctrine into right of publicity law would not be advisable.").

172. See Comedy III, 25 Cal. 4th at 406; Hilton, 599 F.3d at 909.

173. See Tushnet, supra note 34 , at 180.

174. Winter, 69 P.3d at 479; see also Berger, supra note 58, at 854.

175. Tushnet, supra note 34, at 180; see also Kirby, 144 Cal. App. 4th at 60 ("Whether the Ulala character conveys any expressive meaning is irrelevant to a First Amendment defense.").

176. Kirby, 144 Cal. App. 4th at 60 (internal quotations omitted).

177. See joudama, supra note 17; Kristina, supra note 16; see also Comedy III, $25 \mathrm{Cal}$. 4 th at 409.

178. See Comedy III, 25 Cal. 4th at 409; Lee, supra note 105, at 500.

179. Comedy III, 21 P.3d at 799; see also ETW, 332 F.3d at 933.

180. See Blanke, supra note 50, at 382; Lee, supra note 105, at 493 ("This 'transformativeness' test has apparently already proven problematic.'). 
Journal of Law, Technology \& the Internet $\cdot$ Vol. $7 \cdot 2016$

When Real People Become Fictional

judgments. ${ }^{181}$ Courts have merely stated that it must be more than "merely trivial." ${ }^{182}$ Here is where the aggressive fictionality of online stories about celebrities steps in to protect them. Courts more readily protect fictional endeavors than documentaries in the right of publicity context. ${ }^{183}$ The recent cases In re NCAA Student-Athlete Name \& Likeness Litigation ${ }^{184}$ and Hart v. Electronic Arts, Inc., ${ }^{185}$ condemned a videogame for using likenesses of collegiate athletes. A videogame, like a movie or a story, is a creative expression. However, the court's language in these cases questioned the fictionality of the videogame at issue, noting that it attempted to hew as closely to the real-life athletic attributes of the football players as possible. Everything about the videogame was described as "realistic." 186 The football players at issue in the game did everything the same way the football players did in real life. ${ }^{187}$ In other words, the court did not see the videogame as fictional enough. ${ }^{188}$

The same can be said of No Doubt v. Activision Publishing, Inc. ${ }^{189}$ In that case, the band No Doubt was depicted in exactly the environment and activity in which they had achieved its fame: as singers performing rock songs. ${ }^{190}$ Again, the videogame was not fictional enough; the band members were not transformed in any way. ${ }^{191}$ The likenesses in the videogame were nothing more than "conventional, more or less fungible, images" of the band members. ${ }^{192}$ The "overall goal" of the videogame was to set forth a "conventional portrait" of No Doubt. ${ }^{193}$ The videogame maker was not making any expressive comment about No Doubt but was acting exactly as a licensee of No Doubt's publicity right would have acted. ${ }^{194}$

In contrast to the works that have raised courts' concerns, little about online stories about celebrities could be termed "realistic." The more outrageous and "fanciful" online stories about celebrities get, the more significant creativity has been added, the more transformative they become, the more protected they are. ${ }^{195}$ Most of what's involved in fanfiction RPF

181. See Tushnet, supra note 34, at 170; Hart, 717 F.3d 141 at 154.

182. Winter, 69 P.3d at 478; see also Kirby, 144 Cal. App. 4th at 60.

183. See Tushnet, supra note 34, at 165.

184. See In re NCAA, 724 F.3d 1268.

185. 717 F.3d 141 (3rd Cir. 2013).

186. Hart, 717 F.3d at 168; see also Allen, 610 F. Supp. at 623.

187. See Hart, 717 F.3d at 166.

188. See also id. at 168 (noting that the "heightened realism" of the game is part of its value).

189. 122 Cal. Rptr. 3d 397 (Ct. App. 2011).

190. See No Doubt, 122 Cal. Rptr. 3d at 410-11.

191. See No Doubt, 192 Cal. App. 4th at 1034.

192. No Doubt, 192 Cal. App. 4th at 1035 (quoting Comedy III, 25 Cal. 4th at 405).

193. Id. (quoting Comedy III, 25 Cal. 4th at 408).

194. See No Doubt, 122 Cal. App. 4th at 1042 (Epstein, J., concurring).

195. See Blanke, supra note 50, at 395 (speculating that "[h] $\mathrm{h}$ aving the ability to levitate opposing players or to disappear may be the beginning of a sufficient enough transformation to warrant First Amendment protection" of a college football video game); Hilton, 599 F.3d at 911. 
is made up. This creativity is normally sufficient to protect a form of expression from publicity rights claims. ${ }^{196}$

Imagining celebrities in the zombie apocalypse, or as baristas or college students, or as single fathers, or even as people of an entirely different sexuality with all of the attendant consequences, seems like more than "merely trivial" changes to the celebrity's identity. In none of these stories is the celebrity "depict[ed] literally." "197 Although the celebrities might be "recognizable" from their depictions within the online stories, a publicity right violation must find them to be the equivalent of "as a matter of law, ... a portrait or picture of" the celebrity. ${ }^{198}$ Merely "mak[ing] reference" to the celebrity is not enough. ${ }^{199}$

Online stories about celebrities go beyond making reference to celebrities. They take the celebrities and "place [them] in a new world.",200 Aggressively fictional online stories about celebrities, where Mark Zuckerburg is fighting zombies, seem tailor-made to be protected by existing publicity right precedent. These are not "minor... enhancements." 201 They are "much more than a mere literal likeness." After all, a "fantastic setting and ... monstrous heritage" was what helped make the Winter Brothers comic permissible. ${ }^{203}$ "[D]oing exactly what they do as celebrities," on the other hand, was part of what condemned the videogame in No Doubt. ${ }^{204}$

A work need not be "parody or high-brow art." 205 It need only transform the celebrity in some way. One might debate whether online stories about celebrities are parodies or high-brow art, but it is clear that these online stories transform the celebrity in some way.

\section{Name Changes and Disclaimers}

One might argue that online stories about celebrities should at least be forced to change the celebrities' names. Many of the permissible cases of mainstream stories about celebrities do involve name changes. For instance, the Autumn Brothers is an obvious play off of Winter Brothers, but with a name change. ${ }^{206}$ In addition, many writers who air grievances with thinly veiled portraits of those who have crossed them protect

196. See Hart, 717 F.3d at 164.

197. Winter, 69 P.3d at 479; see also Kirby, 144 Cal. App. 4th at 59; Comedy III, 25 Cal. 4 th at 405 .

198. Allen, 610 F. Supp. at 624.

199. Id.

200. Hollows, supra note 103, at 293.

201. Kirby, 144 Cal. App. 4th at 60.

202. ETW, 332 F.3d at 936 .

203. Tushnet, supra note 34 , at 174.

204. 192 Cal. App. 4th at 1034.

205. Hilton, 599 F.3d at 910

206. Winter, $30 \mathrm{Cal}$. 4 th at 886. 
Journal of Law, Technology \& the Internet $\cdot$ Vol. $7 \cdot 2016$

When Real People Become Fictional

themselves with the precaution of changing the character's name, even if everyone knows who the writer is discussing. ${ }^{207}$

However, under the current state of the law, name changes are not required to be protected from publicity rights violations. ${ }^{208}$ Indeed, an archbishop lost a case in which he was depicted in a novel by name plotting an assassination. ${ }^{209}$ If a minor public personage like an archbishop cannot stop a writer from portraying him as a murderer, it is hard to argue that a major public personage like Harry Styles can stop a writer from portraying him as a college student.

At any rate, it is unclear if there is any real purpose to changing the names if everyone knows who the author is talking about anyway. ${ }^{210}$ "After" changed the names involved but embraced the fact that the names had originally been those of the One Direction band members. ${ }^{211}$ In fact, focusing on the technicality of the name makes little sense if the rest of the expression is original, in the same way that a change of name should not be enough to escape copyright infringement liability that might otherwise exist. $^{212}$ If one is alarmed about online stories about celebrities, allowing the stories to be published with the readers knowing exactly who the author is referencing, protected only by a winking name change, seems to accomplish little. ${ }^{213}$

Perhaps one might at least wish to require the use of a disclaimer. However, the clarifying effectiveness of disclaimers is uncertain. ${ }^{214}$ Certainly the use of disclaimers in more mainstream stories about

207. See Trinity, supra note 14; sinensis, supra note 73; History of Real Person Fic, supra note 22; Matthews, 15 F.3d at 436 (There is substantial evidence that the character 'Jim Raynor' in RUSH is based upon Matthews and that the public recognized him as that character.").

208. See also C.B.C., 443 F. Supp. 2d at 1091.

209. See Marcinkus, 522 N.Y.S.2d at 1010.

210. See hederahelix, supra note 15 (discussing online stories about William Shatner and Leonard Nimoy from Star Trek "in which the names had been changed to something else," but "[e]ven so, everyone knew who it was"); queenofhell, Comment to some anti-RPS arguments that I do not understand, LIVEJOURNAL (Mar. 25, 2005, 9:24 PM), http://queenofhell.livejournal.com/2005/03/24/; Emily_shore, supra note 30; Matthews, 15 F.3d at 436.

211. See Minkel, supra note 11.

212. Kate Romahenkova, The Fandom Problem: A Precarious Intersection of Fanfiction of Copyright, 18 INTELL. Prop. L. Bull. 183, 192-93 (Spring 2014).

213. See Anonymous, Comment to 'After' Movie: Paramount Acquires Rights to Wattpad Book by Anna Todd, DeAdline (Oct. 16, 2014, 8:00 AM), http://deadline.com/2014/10/after-movie-rights-wattpad-book-anna-toddparamount-852926/ ("In the edited published version, h.s is Hardin Scott And [sic] all the 1D characters have different names (I.e Liam >landon, niall $>$ nate ) so it doesn't matter"); Kois, supra note 9.

214. See Allen, 610 F. Supp. at 629. (Behavior toward disclaimers suggests that people are inured to their impact or find them pointless or unnecessary..) See Keane, supra note 56, http://www.trickster.org/symposium/symp105.html ("And yes, I realize slash isn't true, I don't think it is, blah blah disclaimer cakes."); Kristina, supra note 16 ("[T]here's not the need for constant disclaimers ... . The default mode of discussion is 'through the veil' [of fantasy].") (quoting Marythefan). 
celebrities does not explain where the line between truthfulness and falsity lies. ${ }^{215}$ Sometimes, for instance, the disclaimer may proclaim everything in the story to be fictional when there is substantial evidence that the story is based upon truth, undermining the effectiveness of the disclaimer. ${ }^{216}$ At any rate, to the extent that disclaimers are effective protection, many online stories about celebrities already use them. ${ }^{217}$

\section{Stealing Attention}

Online stories about celebrities violates publicity rights because such stories are using celebrities to attract attention the stories would not otherwise attract. ${ }^{218}$ "[U]sing a celebrity's identity 'solely to attract attention' to something unrelated to that person can subject the user to liability." 219 If one is using a celebrity's name or likeness to attract attention to one's commercial endeavor without the celebrity's permission, then one runs afoul of that celebrity's publicity rights. ${ }^{220}$ So, for instance, it was a violation of the publicity rights of the Three Stooges to sell t-shirts with their images on them, ${ }^{221}$ and a violation of the publicity rights of Rosa Parks to name a song after her when that song otherwise had nothing to do with the civil rights movement. ${ }^{222}$ Likewise, courts have found publicity rights violations where the images of actors playing well-known fictional characters were being used to publicize products. ${ }^{22}$

Generally, the "stealing attention" condemnation can be found in cases whose essential facts seem to distinguish them from online stories about

215. See Sloan, supra note 88.

216. See Matthews, 15 F.3d at 436.

217. See Sloan, supra note 29; sinensis, supra note 73; nopseud, supra note 17; angrybabble, Comment to RPF?!, FANTHROPOLOGY - THE StUdy OF FANDOM (Aug. 11, 2005, 10:47 PM), http://fanthropology.livejournal.com/117158.html; pensnest, Comment to RPS and privacy, LivEJouRnAL (Apr. 29, 2007, 8:34 AM), http://ignazwisdom.livejournal.com/2007/04/29/; ignazwisdom, Comment to RPS and privacy, LIVEJournal (Apr. 29, 2007, 9:22 PM), http://ignazwisdom.livejournal.com/2007/04/29/; druidspell, Comment to RPS and privacy, LIVEJOURNAL (Apr. 29, 2007, 7:26 PM), http://ignazwisdom.livejournal.com/2007/04/29/; msilverstar, Comment to RPS and privacy, LIVEJOURNAL (Apr. 29, 2007, 8:12 PM), http://ignazwisdom.livejournal.com/2007/04/29/; queenofhell, supra note 78; turnyourankle, this is what $i$ do when $i$ should be cleaning, LIVEJOURNAL (Dec. 8, 2007, 3:56 PM), http://turnyourankle.livejournal.com/2007/12/08/; Emily_shore, supra note 30; kalpurna, Comment to Just beautiful, LiVEJOURNAL (Jan. 4, 2008, 10:09:52 PM), http://kalpurna.livejournal.com/2008/01/04/.

218. See Redish \& Shust, supra note 33, at 1474; Eastwood, 149 Cal. App. 3d at 420.

219. Redish \& Shust, supra note 33, at 1477; see also Hart, 717 F.3d 141; C.B.C., 443 F. Supp. 2d at 1085; ETW, 332 F.3d at 930-31; Doe, 110 S.W.3d at 371.

220. See Wendt, 125 F.3d at 810.

221. Comedy III, 25 Cal. 4th at 401.

222. Parks v. LaFace Records, 329 F.3d 437 (6th Cir.).. 2003).

223. See Berger, supra note 58, at 847 ; Wendt, 125 F.3d at 811 . 
celebrities. ${ }^{224}$ In all of these cases, the celebrities were being exploited to increase the profitability of the business. ${ }^{225}$ Courts seem mostly concerned where the expressive content at issue is "predominantly... intended to capitalize on the commercial value of an individual's identity by permitting the public to purchase a symbolic representation of that identity." ${ }^{226}$ The courts are worried about those activities that would "threaten the market for celebrity memorabilia." 227 The alleged wrongdoer must be taking "something free for which it would otherwise be required to pay.,"228 The consumer of the item or media at issue must reach for it entirely because of the presence of the celebrity and not because of any skill underlying the product. ${ }^{229}$ Even then, using a celebrity "to increase a product's value and marketability" is not necessarily enough on its own to establish a right of publicity violation. ${ }^{230}$ Rather, these cases tend to contain an element of deliberate deceptive wrongdoing or fraud that is absent from online stories about celebrities.

For instance, even though the main attraction of a fantasy game might indeed be the inclusion of the celebrity athletes, such use of the athletes is not necessarily a publicity right violation. ${ }^{231}$ On the other hand, it was a violation of a publicity right where one has an "intent to create the impression that [the celebrity] was somehow associated with the" work, ${ }^{232}$ and where, moreover, the users of the celebrity's likeness had denied that they were making any "expressive comment."233 Likewise, it was a violation of a publicity right where the author of the piece gained "a commercial advantage" by publishing something "allegedly false but presented as true." ${ }^{, 234}$ Even in such a case, though, courts have held that any injunction issued must be sure to leave room for the wrongdoer to "engag[e] in a variety of expressive activities ... undoubtedly protected by the First Amendment." 235

The online stories so radically change the celebrity likenessincluding, at times, changing the names, as in the "After" novelizationsthat they don't seem to be the symbolic representation courts worry about. They are, instead, "a distorted image of a celebrity" that "is a poor substitute for more conventional forms of celebrity depictions." "236 In fact,

224. See Redish \& Shust, supra note 33, at 1455-56 (noting the belief that publicity rights return value to the proper party, away from "those merely seeking to profit").

225. See Berger, supra note 58, at 847; Wendt, 125 F.3d at 811.

226. Lee, supra note 105 , at 500.

227. Kirby, 144 Cal. App. 4th at 58.

228. C.B.C., 443 F. Supp. 2d at 1091

229. See Lee, supra note 105, at 500; ETW, 332 F.3d at 960(Clay, J., dissenting).

230. Hart, 717 F.3d at 173 (Ambro, J., dissenting).

231. See C.B.C., 443 F. Supp. 2d at 1086.

232. Doe, 110 S.W.3d at 371.

233. Id. at 374 .

234. Eastwood, 149 Cal. App. 3d at 420.

235. Doe, 110 S.W.3d at 375.

236. Kirby, 144 Cal. App. 4th at 58. 
commentators have suggested that courts wish to ensure that "the use was intended to make a genuine comment" rather than merely exploiting the celebrity. ${ }^{237}$ If the value of the challenged work comes "from the creativity, skill and reputation" of the creator rather than the notoriety of the celebrity, then it does not run afoul of publicity rights. ${ }^{238}$ Online stories about celebrities seem to deliberately integrate facts into their fiction in a way that indicates serious intent to make a genuine comment. These are not stories titled "Harry Styles Goes to College" that have nothing to do with Harry Styles.

Neither are they exact portraits of Harry Styles. ${ }^{239}$ Rather than merely exploiting the celebrity, ${ }^{240}$ all online stories about celebrities involve some creative effort and re-working in service of a statement. While there may be an argument that online stories about celebrities expose "a mere sliver of the whole" person, ${ }^{241}$ these stories are engaging creatively with the sliver that is exposed. The fact that it is only a sliver merely reinforces that there has been no privacy right violation in a quest for more. In many online stories about celebrities, the only overlap between the story and the "real people" is names, physical characteristics, occasionally some basic background facts, and whatever personality traits a fan believes he/she can glean from the real person's public interactions. ${ }^{242}$ This is all information "in the public domain"; it is nothing that we would ordinarily expect people to pay to use. ${ }^{243}$ "[T] form" is usually not considered a right of publicity violation. ${ }^{244}$

The aggressive fictionality of the online stories serves as the extreme creativity that protects such works from being condemned as mere exploitation. "[O]nce a user has made major changes[,] . . . it no longer qualifies as a 'use' of the [celebrity's] identity." 245 Readers of these stories are unlikely to read them in lieu of purchasing memorabilia from the celebrity. Indeed, arguably most of the readers of such stories are the sort of passionate fans most likely to purchase such memorabilia. Comments to the stories praise the "creativity, skill and reputation" of the online writers. Those that become most popular owe something to the writer, beyond the mere presence of the celebrity. Online stories about celebrities therefore straddle the line between creativity and exploitation that renders them legally permissible.

237. Lee, supra note 105, at 501; see also Doe, 110 S.W.3d at 372 (noting that the use of the celebrity's identity would have been acceptable if it was "for the purpose of communicating information or expressive ideas about that person").

238. Noriega, 2014 WL 5930149, at*4.; Comedy III, 25 Cal. 4th at 407.

239. See, e.g., ETW, 332 F.3d at 936

240. See Redish \& Shust, supra note 33, at 1474.

241. Trinity, supra note 14.

242. See Keane, supra note 56; Kristina, supra note 16.

243. C.B.C., 443 F. Supp. $2 \mathrm{~d}$ at 1091.

244. Tushnet, supra note 34, at 163.

245. Hart, 717 F.3d at 169 


\section{POLICY CONSIDERATIONS SUPPORTING THE LEGALITY OF ONLINE STORIES ABOUT CELEBRITIES}

Current precedent indicates that online stories about celebrities are legally permissible. This is an outcome that makes sense when one considers the purported purpose of the overlapping, intertwined regimes of intellectual property law, publicity rights, and privacy rights. Courts and Congress have sought to strike a balance that encourages creativity and promotes progress. Publicity rights exist to catch those activities that fall in the gap between the intellectual property protection of copyright and trademark law and the tort protection of privacy rights, but they do not create broad property rights. Rather, they should be used "only where the failure to do so would result in the excessive exploitation of" celebrities. ${ }^{246}$

The Supreme Court's asserted purpose behind the initial recognition of publicity rights worries about deterring the creativity of celebrities like the Human Cannonball: " $[\mathrm{T}]$ he protection provides an economic incentive for [the performer] to make the investment required to produce a performance of interest to the public." 247 The Supreme Court wished the right "to promote investment in development of a skill," 248 "to protect the entertainer's incentive in order to encourage the production of this type of work." 49 This incentive motive was important to the Court's holding. Publicity rights are justified not by "a desire to compensate the performer," but with a larger societal benefit in mind. ${ }^{250}$ Other courts have noted that publicity rights should be "socially beneficial" and "encourage[] people to develop special skills."251

Looked at from this perspective, it doesn't seem as if the presence of these online stories is discouraging people from becoming celebrities. In fact, far from it. American society has never had so many celebrities. Given this, some commentators have questioned whether any right of publicity is necessary to induce people to seek fame. ${ }^{252}$ "[T] he additional inducement for achievement produced by publicity rights are often inconsequential because most celebrities with valuable commercial identities are already handsomely compensated." 253

A strong argument can be made that celebrities are adequately rewarded by publicity rights as they have already developed, which has

246. Matthews, 15 F.3d at 438

247. Zacchini, 433 U.S. at 576.; see also Redish \& Shust, supra note 33, at 1462 ("[L]egal protection is a needed incremental inducement to venture onto the stage of public opinion" (internal quotations omitted)); Tushnet, supra note 34, at 181 .

248. Hollows, supra note 103, at 301.

249. Zacchini, 433 U.S. at 577.

250. Id. at 576 .

251. Matthews, 15 F.3d at 437; see also Hart, 717 F.3d at 151.

252. See Redish \& Shust, supra note 33, at 1463; Cardtoons, 95 F.3d at 974.; Comedy III, 25 Cal. 4th at 401.; Rothman, supra note 90, at 245; ETW, 332 F.3d at 930.

253. Cardtoons, 95 F.3 at 974. 
already expanded far beyond that contemplated in Zacchini, ${ }^{254}$ and that further expansion to online stories about celebrities is not needed and would only serve to pointlessly infringe on First-Amendment-protected creative speech. ${ }^{255}$ After all, online stories about celebrities hardly "go to the heart of the [celebrities'] ability to earn a living as [a celebrity]." 256 There is little indication or reason to believe that online stories about celebrities affect the earning power of those celebrities in any way. ${ }^{257} \mathrm{In}$ fact, there is some suggestion that certain uses of celebrity likenesses could in fact increase their fame and their marketing opportunities. ${ }^{258}$ Far from coopting the entire performance the way the news report did in Zacchini, the activities of these writers of online stories about celebrities seem to be engaging in "the incidental use of a name" in a manner that the Court didn't consider to rise to the level of a publicity right violation. ${ }^{259}$ In fact, their aggressive fictionality renders them "poor substitute[s]" for the celebrities themselves and therefore should have no effect on celebrity marketability. ${ }^{260}$

One might argue that there is no very good reason to structure the law to encourage online stories about celebrities. This would appear to be untrue, though. Courts have acknowledged that "celebrities are an important part of our public vocabulary and have come to symbolize certain ideas and values." ${ }^{261}$ A cursory glance at recent Oscars ceremonies supports this notion and proves that stories about real people are one of society's primary forms of communication. ${ }^{262}$ These stories do not strictly adhere to the truth, nor are they legally required to. It would be odd to sweep online stories about celebrities under the rug as unimportant when more mainstream versions of those stories are given central importance.

Moreover, it would be curious to establish a policy against aggressively fictional online stories about celebrities that are unlikely to be regarded as true while simultaneously encouraging more believable stories that may contain falsehoods. Surely there is more harm in stories that are likely to trick people into believing things that are untrue, ${ }^{263}$ like a story

254. See Rothman, supra note 90, at 244. (Indeed, publicity rights now cover celebrities who have done nothing to earn the extra marketing potential.). See Fraley, 830 F. Supp. $2 \mathrm{~d}$ at 808.

255. See, e.g., Berger, supra note 58, at 847.

256. C.B.C., 443 F. Supp. $2 \mathrm{~d}$ at 1091.

257. See ETW, 332 F.2d at 938; Fraley, 830 F. Supp. 2d at 807 . Moreover, even when that happens, courts seem relatively unconcerned if the work using the celebrity's likeness is an expressive one. See Ninth Circuit Tosses Hurt Locker Case, RothMAN's RoAdMAP TO THE Right OF Publicity (Feb. 17, 2016)).

258. See C.B.C., 443 F. Supp. 2d at 1091.

259. Zacchini, 433 U.S. at 576.

260. Kirby, 144 Cal. App. 4th at 58.

261. ETW, 332 F.3d at 933 .

262. See also In re NCAA, 724 F.3d at 1290 (Thomas, J., dissenting).

263. See sinensis, supra note 73; Kristina, supra note 16; pensnest, Comment to RPS and privacy, LiveJournal (Apr. 29, 2007, 8:34 AM), http://ignazwisdom.livejournal.com/2007/04/29/; turlough, Comment to RPS and 
Journal of Law, Technology \& the Internet · Vol. $7 \cdot 2016$

When Real People Become Fictional

that the President of the United States is a Muslim who was born in Africa. Indeed, many of the arguments against online stories about celebrities seem to presuppose that people are going to believe the stories, an acknowledgment that it is the possible belief in untrue things that causes discomfort. $^{264}$ To permit believable stories but prohibit outrageous fictionalizations would be counterintuitive to the purpose of allowing celebrities some control over their public persona: They will have lost control of the area most likely to cause them harm. ${ }^{265}$

Some critics have posited that it is impossible to maintain control over one's identity "in a free and open society." "266 If that is the case, though, one might wish to encourage more online stories about celebrities to steer people away from more believable fictions. In that way, the celebrity may still be able to exercise some modicum of control, drowning out the stories that would most likely damage their reputation. ${ }^{267}$ If the law needs to be adjusted to protect celebrities more, the place to start would surely be these more mainstream forms of creativity, not the online stories.

The laws in this arena are a very careful balance, ${ }^{268}$ and prohibiting all stories being told about a celebrity would result in a tremendous amount of creative speech being blocked, ${ }^{269}$ with uncertain corresponding upside. ${ }^{270}$ It is worth noting that, in the case of mainstream stories about celebrities, this is creative speech that is seen as superior to much other speech. Some amount of control over creative stories about yourself is part of the sacrifice of "[s]tepping into the public eye." 271 "[P] rominence invites creative comment.",

privacy, LIVEJOURNAL (Apr. 29, 2007, 4:10 PM), http://ignazwisdom.livejournal.com/2007/04/29/.

264. See Kit Mason, RPS: Writing Under the Influence, The FAnfiC SyMPOSIUM (Aug. 12, 2001), http://www.trickster.org/symposium/symp78.html.

265. See Redish \& Shust, supra note 33, at 1459 ("[T]he right of publicity implicates a person's interest in autonomous self-definition, which prevents others from interfering with the meanings and values that the public associates with her.").

266. Id. at 1460 .

267. See Zacchini, 433 U.S. at 580 (Powell, J., dissenting);); Comedy III, 25 Cal. 4th at 403.

268. See In re NCAA, 724 F.3d at 1284 (Thomas, J., dissenting).

269. See Redish \& Shust, supra note 33, at 1467 ("The right of publicity and the First Amendment are obvious adversaries."); Lee, supra note 105, at 501 ("[I]t will chill speech and impoverish discourse ....").

270. Indeed, there are those who believe that publicity rights already result in "censorship of popular culture," even without extending them to RPF. Redish \& Shust, supra note 33, at 1455.

271. Id. at 1460; Trinity, supra note 14; joudama, supra note 17; Kristina, supra note 16; Emily_shore, supra note 30; Matthews, 15 F.3d at 439;.; Eastwood, 149 Cal. App. 3d at 422;:; Zacchini, 433 U.S. at 582 (Powell, J., dissenting). This raises the issue of what should happen if you are thrust into the public eye through no choice of your own. While mainstream RPF tells multiple stories about this type of person, fanfiction RPF revolves practically exclusively around celebrities who engage with the public eye. See queenofhell, supra note 78. Indeed, this engagement is part of the very creativity of the medium. To the extent this is an 
One might argue that there is a public need for the more mainstream stories and not for the online stories, and so the mainstream stories should be more protected while online stories should receive less protection. Courts already examine public need in the context of publicity rights violations, ${ }^{273}$ and find "public need" for stories about celebrities in a wide variety of contexts. ${ }^{274}$ It includes things "less important" than news. ${ }^{275}$ So, for instance, they have found it necessary to protect movies concerning fictionalized accounts of civilian deaths. ${ }^{276}$ If there is a public need for the communication of these fictionalizations of private grief, it is hard to justify why outrageous fictionalizations of public celebrities should be blocked. The public need standard would appear to be very low. ${ }^{277}$

At any rate, the purpose of publicity rights, according to the Supreme Court, was not to promote censorship and decrease the amount available about a celebrity; rather, it was to encourage the continued distribution of the benefit of the celebrity's talents among the public, achieving wide dissemination. ${ }^{278}$ It would be odd to deprive the public of a means of communication that the celebrities themselves are not likely to exploit or license - the opposite of what publicity rights were originally intended to address. As courts have noted: "Giving broad scope to the right of publicity has the potential of allowing a celebrity to accomplish through vigorous exercise of that right the censorship of unflattering commentary that cannot be constitutionally accomplished through defamation actions." 279

Nor is it necessarily true that these online stories about celebrities are serving no public need. From the very first recognition of publicity rights by the Supreme Court in Zacchini, courts have recognized that there is a "public benefit" to have access to celebrities. ${ }^{280}$ "Through their pervasive presence in the media, sports and entertainment celebrities come to symbolize certain ideas and values.... Celebrities, then, are an important element of the shared communicative resources of our cultural domain."281

"Because celebrities take on public meaning, the appropriation of their likenesses may have important uses in uninhibited debate on public issues, particular debates about culture and values. And because celebrities take on personal meaning to many individuals in the society, the creative

issue, it is an issue for the widely accepted mainstream RPF, not the fanfiction version.

272. Guglielmi, 25 Cal. 3d at 869.

273. See Dora, 15 Cal. App. 4th at 542.

274. See, e.g., Stephano, 64 N.Y.2d at 184;.; Eastwood, 149 Cal. App. 3d at 423;.; Dora, 15 Cal. App. 4th at 543;.; ETW, 332 F.3d at 930.

275. Doe, 730 F.3d at 961.

276. Tyne v. Time Warner Entm't Co., L.P., 901 So. 2d 802 (Fla. 2005).

277. See Volokh, supra note 163.

278. See Zacchini, 433 U.S. at 578.

279. Comedy III, $25 \mathrm{Cal}$. 4 th at 398.

280. 433 U.S. at 578.

281. Cardtoons, 95 F.3d at 972; see also ETW, 332 F.3d at 937-38. 
appropriation of celebrity images can be an important avenue of individual expression." 282

Some familiar with the online stories argue that they are exposing a "subtext" that society is otherwise ignoring, ${ }^{283}$ and thus providing value. Others argue that online stories are "a new way to comment on world politics and pop cultural events..."284 Another argument states that these stories are "often a way of playing with the 'fictions' that celebrities perform..." 285 One writer has posited that, in the absence of traditional forms of myth, celebrities function as "new Gods" who "help us to make sense of our own lives," such that the online stories about them can be viewed as necessary mythologies. ${ }^{286}$ And, indeed, pornographic stories about celebrities have played important political roles throughout history. ${ }^{287}$ Courts have also recognized that the "importance of celebrities in society" cautions against the over-application of publicity rights for fear they would block "attempt[s] to redefine the celebrity's meaning.",288

Finally, it should not be the place of intellectual property or publicity rights law to engage in the practice of determining if a piece of creativity is allowed based on an assessment of the need for that particular piece of creativity. ${ }^{289}$ Courts should not "be concerned with the quality of the artistic contribution." 290 Surely such decisions would result in a system of state-sanctioned creativity.

"The First Amendment is not limited to ideas, statements, or positions which are accepted; which are not outrageous; which are decent and popular; which are constructive or have some redeeming element; or which do not deviate from community standards and norms; or which are within prevailing religious or moral standards." 291

Making such a decision would disallow natural disagreement about these issues. There is at least anecdotal evidence that some celebrities are well aware of online stories about them and do not seem bothered by them. ${ }^{292}$ Online stories about celebrities are just that: stories. "No author

282. Comedy III, 25 Cal. 4th at 397.

283. hederahelix, supra note 15.

284. Kristina, supra note 16.

285. Femmenerd, Comment to [ an inspired word will come across your tongue], LiveJournal (Sept.15, 2007, $\quad 1: 01 \quad$ AM), http://winterlive.livejournal.com/389407.html.

286. See joudama, supra note 17; see also Abby Norman, Behind Faves: Why We Grow Emotionally Attached to Celebrities, THE MARY SuE (Aug. 26, 2015).

287. See Michiko Kakutani, Books of the Times: Porn and Politics Under the Ancien Regime, N.Y. TIMES (Aug. 17, 1993); Romano, supra note 16.

288. Comedy III, 25 Cal. 4th at 397.

289. See C.B.C., 443 F. Supp. 2d at 1094; Marcinkus, 138 Misc. 2d at 265; Time, 385 U.S. at 388 .

290. Comedy III, 25 Cal. 4th at 407.

291. Pring, 695 F.2d at 443.

292. See hederahelix, supra note 15; hederahelix, Comment to RPS: Another Persepctive [sic], FANTHROPOlOGY - THE STUdy OF FANDOM (Mar. 22, 2005, 8:52 PM), http://fanthropology.livejournal.com/33447.html; annikaa, Comment to RPS: Another Persepctive [sic], Fanthropology - The Study of FAndom (Mar. 22, 
should be forced into creating mythological worlds or characters wholly divorced from reality." 293

\section{CONCLUSION}

For many years, online stories about celebrities existed in the shadowy underbelly of the fanfiction world, dismissed instinctively as "wrong." An examination of the existing laws, however, reveals that online stories are probably legally permissible. At present, nothing about them sets them apart legally from very widespread and widely accepted forms of storytelling that society embraces and celebrates daily. In fact, that which does set them apart renders these stories probably more legally protected under current precedent than more traditional and well-known forms of fanfiction.

As celebrities continue to grow in prominence as being commercial empires unto themselves, and as stories about them continue to likewise grow in financial reward, a discussion about whether the law should be changed in some way to try to limit these types of stories will no doubt occur. In considering changes to the law, one should think long and hard about the censorship of this sort of speech before rejecting it instinctively. Studies have shown that the writers of these online stories about celebrities are usually voices traditionally excluded from the predominantly white straight male world of mainstream storytelling. That fact must be acknowledged when judging their contributions to the culture. Censoring speech that differs from accepted speech based only on the disfavored status of the speaker is a dangerous path to travel.

2005, 9:19 PM), http://fanthropology.livejournal.com/33447.html; nopseud, supra note 17; Kristina, supra note 16; kalpurna, Just beautiful, LiVEJourNAL (Jan. 4, 2008), http://kalpurna.livejournal.com/2008/01/04/. 293. Guglielmi, 25 Cal. 3d at 869. 
Journal of Law, Technology \& the Internet · Vol. $7 \cdot 2016$

When Real People Become Fictional 